\title{
ANALYSIS OF EFFICIENCY ENHANCEMENT OF FLAT PLATE SOLAR COLLECTOR USING NANOFLUIDS
}

\author{
K. Farhana ${ }^{1,4}$, K. Kadirgama1, R. Saidur ${ }^{2,5}$,D. Ramasamy1, A. S. F. Mahamude ${ }^{3}$ \\ ${ }^{1}$ Faculty of Mechanical Engineering, Universiti Malaysia Pahang, 26600 Pekan, Pahang, \\ Malaysia \\ ${ }^{2}$ Research Centre for Nano-Materials and Energy Technology (RCNMET, Sunway \\ University, Bandar Sunway, Malaysia \\ ${ }^{3}$ Faculty of Chemical \& Natural Resources Engineering, Universiti Malaysia Pahang, \\ 26300 Gambang, Pahang, Malaysia \\ ${ }^{4}$ Department of Apparel Manufacturing Engineering, Bangladesh University of \\ Textiles, Dhaka 1208, Bangladesh \\ ${ }^{5}$ Department of Engineering, Lancaster University, LA1 4YW, United Kingdom
}

Corresponding author:kfarnaha81@yahoo.com,kumaran@ump.edu.my

\begin{abstract}
This study analyses the efficiency enhancement of flat plate solar collector using $\mathrm{Al}_{2} \mathrm{O}_{3}$ and crystal nano-cellulose (CNC) nanofluids. The upward energy demand along with the depletion of conventional energy sources demands improved utilization of renewable energy resources. Among all renewable energy resources, solar energy is the most appropriate alternative to conventional energy sources owing to its inexhaustibility and green property. Solar collectors are devices that convert solar radiation into heat or energy. However, the efficiency of the solar collector is still not adequate. The competent step to enhance the efficiency of the solar collector is to use nanofluids. This study is carried out different phases viz. characterization and stabilization while both qualitative and quantitative methods used to evaluate the stability of nanofluids; several thermo-physical properties of $\mathrm{Al}_{2} \mathrm{O}_{3}$ and $\mathrm{CNC}$ nanofluids such as thermal conductivity measured at four different temperature using KD2 Pro, viscosity and specific heat determined at similar temperature range by viscometer and differential scanning calorimetry respectively; implementation of nanofluids in the solar collector. The experiment is executed with a fixed flow rate and in steady-state conditions under open solar radiation. The experimental study has revealed that up to $2.48 \%$ and $8.46 \%$ efficiency of solar collector enhanced by using $0.5 \% \mathrm{Al}_{2} \mathrm{O}_{3}$ and $0.5 \% \mathrm{CNC}$ nanofluids respectively. Moreover, nanofluids show good to moderate stability performance. In addition, the thermal conductivity of nanofluids increased while viscosity is in decreasing trend with increasing temperature. Applying nanofluids could enhance the efficiency of a flat-plate solar collector.
\end{abstract}

\section{Graphical abstract}




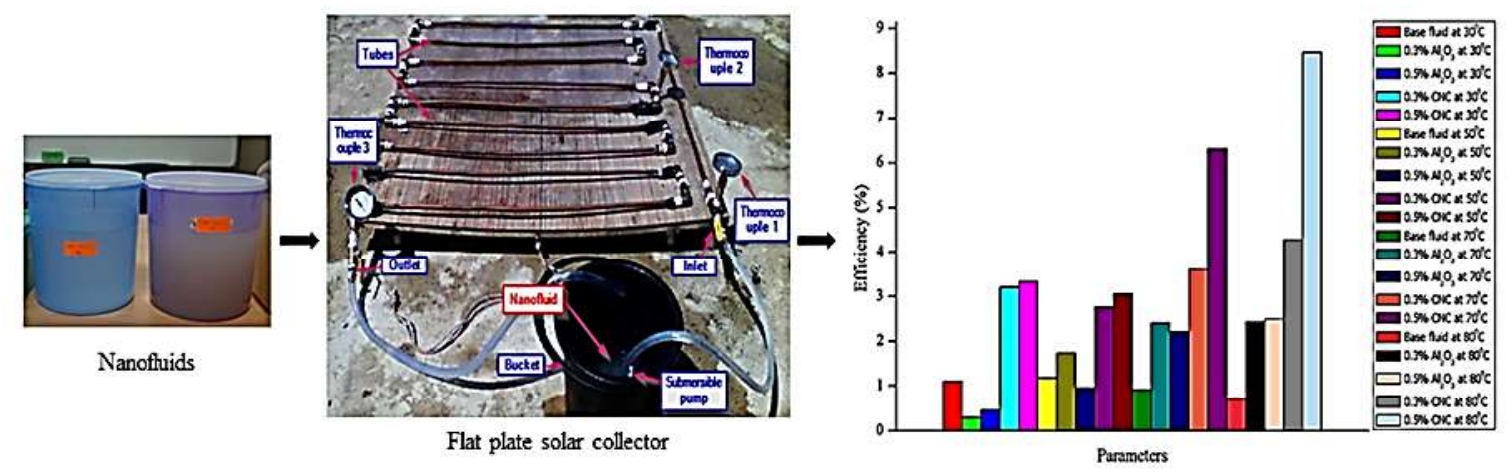

Keywords: Nanofluids; Thermo-physical Properties; Flat Plate Solar Collector; Energy Gain; Efficiency

\section{Introduction}

To fulfill the smart demands of people, the utilization of energy is increasing day by day. As a result, the depletion of fossil energy, as well as its unfavorable response, urges to realize to take necessary actions rapidly $[1,2]$. Therefore, renewable energies are trying to capture the space of fossil energy. solar energy is the most preferable energy among various renewable energies as it is inexhaustible, clear and plentiful [3,4]. To harvest solar energy, the solar collector is one of the most important devices and green invention as well [5]. Solar collector suffering from low energy efficiency. But efficiency can be improved by replacing the working fluids into nanofluids [6]. Newly developed solar collector which is simple and has a wide range of applications specifically in domestic and industrial usages to heat water named flat plate solar collector (FPSC). Although FPSC has a versatile implementation, it is suffering from low energy efficiency. Nanofluid is the most promising and latest method to enhance the efficiency of FPSC [7, 8].

\begin{tabular}{|ll|}
\hline Nomenclature & \\
& The American Society of Heating, \\
& Refrigerating and Air Conditioning Engineers \\
$\mathrm{Al}_{2} \mathrm{O}_{3}$ & Aluminium Oxide \\
$\mathrm{CNC}$ & Crystal nano-cellulose \\
$\mathrm{CSR}$ & Controlled shear rate \\
$\mathrm{CuO}$ & Copper Oxide \\
$\mathrm{DSC}$ & Differential scanning calorimetry \\
\hline
\end{tabular}




\begin{tabular}{|c|c|}
\hline DWCNT & Double-Walled Carbon Nanotube \\
\hline EDX & Energy dispersive $\mathrm{x}$-ray spectroscopy \\
\hline EG & Ethylene glycol \\
\hline ELS & Electrophoretic light scattering \\
\hline FESEM & Field emission scanning electron microscopy \\
\hline FLIR & Forward-looking infrared \\
\hline FPSC & Flat plate solar collector \\
\hline MWCNT & Multi-Walled Carbon Nanotube \\
\hline $\mathrm{MgO}$ & Magnesium Oxide \\
\hline $\mathrm{SiO}_{2}$ & Silicon Dioxide \\
\hline SWCNT & Single-Walled Carbon Nanotube \\
\hline TEM & Transmission electron microscopy \\
\hline $\mathrm{TiO}_{2}$ & Titanium Dioxide \\
\hline $\mathrm{W}$ & Water \\
\hline $\mathrm{ZnO}$ & Zinc Oxide \\
\hline $\mathrm{ZrO}_{2}$ & Zirconium Dioxide \\
\hline \multicolumn{2}{|c|}{ Greek symbols } \\
\hline$\phi$ & Volumetric concentration of particles (\%) \\
\hline$C_{p}$ & Specific heat $(\mathrm{J} / \mathrm{g}-\mathrm{K})$ \\
\hline$w$ & Mass fraction \\
\hline$Q_{u}$ & Energy gain $(\mathrm{kW})$ \\
\hline$\dot{m}$ & Mass flow rate $(\mathrm{kg} / \mathrm{s})$ \\
\hline$I_{t}$ & Incident solar radiation $\left(\mathrm{W} / \mathrm{m}^{2}\right)$ \\
\hline$A_{c}$ & Area of the solar collector $\left(\mathrm{m}^{2}\right)$ \\
\hline$\eta$ & Efficiency $(\%)$ \\
\hline$T$ & Temperature $\left(\mathrm{K}\right.$ or $\left.{ }^{\circ} \mathrm{C}\right)$ \\
\hline$\tau$ & Shear stress \\
\hline$\gamma$ & Shear rate \\
\hline \multicolumn{2}{|l|}{ Subscripts } \\
\hline $\mathrm{p}$ & Particle \\
\hline bf & Base fluid \\
\hline
\end{tabular}


Nanofluid is the latest approach for modern technology to enhance the performance of engineering tools and machinery [9]. Nanofluids prepared by dispersing the nanoparticles into the base fluids [10, 11]. Nanoparticles enable unique properties such as physicochemical, optical and biological properties which can be manipulated suitably in the intended application $[12,13]$. Thermal conductivity and heat transfer coefficient increased significantly by adding a tiny number of nanoparticles into the working fluids as well as further enhancement occurred linearly due to the augmentation of nanoparticles into the base fluid. Moreover, nanofluid exhibits the enhancement of heat transfer, improved suspension stability, high surface volume, fewer particles clogging and anomalous increase in thermal conductivity while the heat transfer or heat transfer coefficient directly related to thermal conductivity. Water and ethylene glycol have been utilized in much nanofluid related research works as a base fluid. However, nanofluids are not only great interest to increase the heat transfer but also improving other properties such as rheological behaviour and mass transfer properties [14-16].

The researchers and scientists have experimented and identified different types of metallic nanoparticles such as $\mathrm{Al}, \mathrm{Fe}, \mathrm{Cu}, \mathrm{Ag}$, and $\mathrm{Au}$; non-metallic nanoparticles such as $\mathrm{CuO}, \mathrm{SiC}$, $\mathrm{Al}_{2} \mathrm{O}_{3}, \mathrm{ZnO}$, semiconductors $\left(\mathrm{TiO}_{2}\right)$, carbon nanotubes (SWCNT, DWCNT, MWCNT) and composites materials such as nanoparticles core polymer shell composites; while most of them are chemically stable and functionalized nanoparticles. Generally, nanoparticles produced by physical and chemical synthesis techniques $[17,18]$. In addition to this, over the last few years nano-cellulose attract more attention to the researchers due to some of their notable properties such as biodegradability, impressive mechanical properties, lower density, plentiful in nature and most importantly eco-friendly aspect as well [19, 20].

In the last few years, the researchers are studying more on the efficiency enhancement of flat plate solar collectors using nanofluids as working fluids in replace of conventional fluids such as Yousefi, Veisy [21] studied the thermal performance of FPSC with MWCNT-water nanofluid and concluded the improvement of collector significantly. Moghadam, Farzane-Gord [22] studied the efficacy of an FPSC increase of $16.7 \%$ when CuO-water nanofluid applied in the solar collector. Said, Sabiha [23] experimentally investigated the output temperature enhancement of FPSC using $\mathrm{TiO}_{2}$-water nanofluid. The authors revealed that nanofluids can maximize the temperature up to $65^{\circ} \mathrm{C}$. In addition, Verma, Tiwari [24] studied the efficiency of FPSC using MgO-water nanofluid and revealed that the efficacy of collector enhanced. Later, Verma, Tiwari [25] again investigated the efficiency performance of FPSC by using various nanofluids such as $\mathrm{CuO}, \mathrm{TiO}_{2}, \mathrm{MWCNT}$, Graphene/water nanofluids and found that 
the MWCNT nanofluid shows the highest increment of efficiency of FPSC. Besides, Ziyadanogullari, Yucel [26] studied the thermal performance of FPSC using $\mathrm{Al}_{2} \mathrm{O}_{3}$. $\mathrm{TiO}_{2}$, $\mathrm{CuO} /$ water nanofluids. The authors concluded that the maximum efficiency of collector achieved by using $\mathrm{CuO}$-water nanofluid while the lowest increase found for $\mathrm{TiO}_{2}$-water nanofluid. Eltaweel and Abdel-Rehim [27] experimentally investigated the efficiency performance of FPSC with MWCNT-water nanofluid. They revealed that the efficiency of $16 \%, 21 \%$, and $34.13 \%$ was higher than distilled water at the concentration of $0.01 \mathrm{wt} \%, 0.05$ $\mathrm{wt} \%$, and $0.1 \mathrm{wt} \%$ nanofluids respectively.

This study aims to analyse the efficiency improvement of the flat plate solar collector by using nanofluids. The focus will be on the inorganic $\left(\mathrm{Al}_{2} \mathrm{O}_{3}\right)$ and organic $(\mathrm{CNC})$ nanofluids implementation in FPSC successively, which is incomparable with any study in the literature. Moreover, in this study, the efficiency of FPSC will be analysed considering the tubes (header and riser) of FPSC through which the nanofluids can circulate. Thereby, the $\mathrm{Al}_{2} \mathrm{O}_{3}$ and $\mathrm{CNC}$ nanoparticles will be characterized and prepared by standard method; thermo-physical performances of nanofluids will be evaluated and finally, nanofluids will be applied in FPSC to observe the efficiency enhancement of collector in the steady-state condition under solar radiation. The result will be compared with other studies which are near it.

\section{Material and Methods}

In this study, aluminium oxide $\left(\mathrm{Al}_{2} \mathrm{O}_{3}\right)$ anhydrous nanoparticles used which was procured from Bendosen Laboratory Chemicals. CNC nanoparticle used and was purchased from Blue Goose Biorefiners Inc. company with a weight concentration of $8.0 \% \mathrm{w} / \mathrm{w}$. The specification of CNC nanoparticles was provided by the company as presented in Table 1. EG with water (W: EG 60: 40 ratio) has been selected as the base or working fluids.

Besides, the specification of flat plate solar collector (FPSC) especially the tubes (header and riser) has been described in Table 2. The efficiency of FPSC has been calculated by the following (Eq. (1 and 2)).

$Q_{u}=\dot{m} C_{p} T_{\text {out }}-T_{\text {in }}$

$\eta=\frac{Q_{u}}{I_{t} A_{c}}$ 
Where $\eta$ is the efficiency (\%); $Q_{u}$ is the energy gain $(\mathrm{kW}) ; \dot{m}$ is the mass flow rate $(\mathrm{kg} / \mathrm{s}) ; C_{p}$ is the specific heat $(\mathrm{J} / \mathrm{g}-\mathrm{K}) ; I_{t}$ is the solar radiance $\left(\mathrm{W} / \mathrm{m}^{2}\right) ; A_{c}$ is the total area of the solar collector $\left(\mathrm{m}^{2}\right) ; T_{\text {out }}$ and $T_{\text {in }}$ are the outlet and inlet temperature $\left({ }^{\circ} \mathrm{C}\right)$ respectively. Moreover, In this study, solar radiance has been considered as a constant value of $830 \mathrm{~W} / \mathrm{m}^{2}$ which was selected from the experimental work of solar collector performed by Gaos, Yulianto [28]. The authors found the maximum average value of solar radiance was $830 \mathrm{~W} / \mathrm{m}^{2}$ during the evaluation of the performance of the solar collector significantly.

\subsection{Characterization and Preparation of Nanofluids}

The nanoparticles $\left(\mathrm{Al}_{2} \mathrm{O}_{3}\right.$ and $\left.\mathrm{CNC}\right)$ were characterized by using different characterization equipment such as Field-emission scanning electron spectroscopy (FESEM), Transmission electron microscopy (TEM) [29-32]. In this study, the two-step method has been used to prepare the nanofluids as similar to many previous studies such as Ramachandran, Hussein [33] and Azmi, Hamid [34]. Nanoparticles $\left(\mathrm{Al}_{2} \mathrm{O}_{3}\right.$ and $\left.\mathrm{CNC}\right)$ were suspended in the base fluid (W: EG 60:40) at different volume fractions such as $0.1 \%, 0.3 \%$, and $0.5 \%$ and then mixed/blended it using a magnetic stirrer until proper mixing. The required mass of nanoparticles in a dry form corresponding to the volume concentration was calculated using (Eq.(3)) [35].

$\phi=\frac{\frac{w}{\rho_{p}}}{\frac{w}{\rho_{p}}+\frac{w_{b f}}{\rho_{b f}}} \times 100$

Where $\phi$ is the volume concentration of nanofluids (\%), $w$ is the mass fraction and $\rho$ stands for density. The subscripts $p$ and $b f$ stand for nanoparticles and base fluid respectively.

Afterward, sonication has been done using probe sonication processor until no agglomerates could be observed in the suspension [36]. Fig. 1 shows the preparation method for nanofluids. Sonication of nanofluids is very necessary to prepare stable nanofluids by disperse the nanoparticles into the base fluids uniformly and to avoid agglomeration or agitation of nanoparticles.

\subsection{Measurement of Thermo-physical Properties}

The stability of $\mathrm{Al}_{2} \mathrm{O}_{3}$ and $\mathrm{CNC}$ nanofluids have been measured by qualitative and quantitative methods. In the case of the quantitative method, to measure the stability of both nanofluids 
litesizer 500 zeta potential (Anton Paar, Austria) used. ELS (electrophoretic light scattering). Omega Cuvette measurement cell used to evaluate the electro kinetic potential in colloidal dispersion. The zeta potential values obtained in the millivolt [37]. Sedimentation observation (Qualitative method) has been done by naked eyes to examine the stability of $\mathrm{Al}_{2} \mathrm{O}_{3}$ and $\mathrm{CNC}$ nanofluids at various volume concentrations similarly with Kadirgama, Anamalai [38] conducted the qualitative method to measure the stability of nanofluids in thermal analysis of SUS 304 stainless steel using nano-cellulose/ethylene glycol-based study.

Thermal conductivity of the base fluid, $\mathrm{Al}_{2} \mathrm{O}_{3}$, and $\mathrm{CNC}$ nanofluid at $0.1 \%, 0.3 \%$, and $0.5 \%$ volume concentrations were measured by KD2 Pro Thermal Property Analyser (Decagon Devices, Inc., USA. The transient hot-wire method was the operating principle of that device. KD2 Pro consists of a handheld controller and a sensor. This sensor can measure the thermal conductivity between $0.002-2.00 \mathrm{~W} / \mathrm{m}-\mathrm{K}$ with an accuracy of $\pm 5 \%$. The experiment was performed at a temperature range of $30^{\circ} \mathrm{C}$ to $80^{\circ} \mathrm{C}$ (controlled condition). Before starting the actual sample measurement, the sensor was validated by measuring the thermal conductivity of glycerine $\left(\mathrm{k}=0.282 \mathrm{~W} / \mathrm{m}-\mathrm{K}\right.$ at $20^{\circ} \mathrm{C}$; solution provided by the manufacturer. Moreover, the thermal conductivity measurement verified by measuring the base fluid $(60 \%$ water and $40 \%$ ethylene glycol) and compared with predetermined values of ASHRAE standard (American Society of Heating, Refrigerating and Air Conditioning Engineers). The maximum deviation between the base fluid and ASHRAE data was 3.2\%. Previously many researchers used KD2 Pro Thermal Property Analyser to measure the thermal conductivity of nanofluids in experimental studies [39-42].

In this study, the dynamic viscosity of CNC nanofluids with various volume concentrations was measured at a temperature range of $30^{\circ} \mathrm{C}$ to $80^{\circ} \mathrm{C}$ by Brookfield RST, Coaxial Cylinder rheometer. And the dynamic viscosity of $\mathrm{Al}_{2} \mathrm{O}_{3}$ nanofluids measured at the same range of temperature by Malvern Panalytical (model Kinexus lab+) manufactured by Malvern Panalytical Ltd, United Kingdom. At first, the viscosity of base fluid was measured and compared the obtained values with the prementioned data of the ASHRAE standard. The rotational measurement under controlled shear rate (CSR) method used. Previously many studies used Brookfield RST and Malvern Panalytical in order to measure the viscosity of nanofluids [34, 43].

Differential scanning calorimetry (DSC) is a highly sensitive technique can be used to measure the specific heat capacity $\left(C_{p}\right)$ of both solid and fluids $[44,45]$. Here specific heat of nanofluids 
(both $\mathrm{Al}_{2} \mathrm{O}_{3}$ and $\mathrm{CNC}$ ) at various volume concentrations has been measured using the Linseis DSC 1000 (Differential scanning calorimetry-Germany). In this study, the weight of all samples was fixed at $13 \mathrm{mg}$ weighing by electrical balance and that has been loaded in aluminium crucibles. Fig. 2 shows the specific heat measurement tools. This equipment gives the highest possible accuracy of $C_{p}$ by using modulated heating rate temperature profiles. This method defines a steady change in the heat flow of the samples and the system can observe the heat uptake superiorly than a linear heating system [46]. Besides, $C_{p}$ measurement could be affected by the mass value of the materials and the heating rate owing to the use of the DSC [47].

\subsection{Application of Nanofluids in FPSC}

Two types of volume concentrations have been preferred based on the performance of thermophysical properties of both $\left(\mathrm{Al}_{2} \mathrm{O}_{3}\right.$ and $\left.\mathrm{CNC}\right)$ nanofluids such as $0.3 \%$ and $0.5 \%$ to apply in FPSC. The experiment has been run during day time (sunny day) from 10.00 am to $2.00 \mathrm{pm}$ and the location was University Malaysia Pahang [48]. Forward-looking infrared (FLIR) thermal camera has been used to measure the surface temperature of copper tubes. Fig. 3 presents the experimental setup and Table 3 shows the list of apparatus of the experimental setup of the collector with properties.

Prior to starting the measurement of temperature by FLIR thermal camera, FLIR has been calibrated by sensing the temperature of hot water. To avoid the error data ten reading has been taken in maximum temperatures and calculated the average of the hot water around $84.94{ }^{\circ} \mathrm{C}$. Before applying the nanofluids in FPSC, the flow rate of the submersible pump has been checked with water by adjusting the flow control of the pump. At the very beginning of the running of this experiment, the inner and outer thermocouple shows the unprecedented temperature difference data between them. To ignore this error reading, three types of observation has been done. After starting equipment, the data has been checked after $10 \mathrm{~min}$, $30 \mathrm{~min}$, and $60 \mathrm{~min}$ consecutively; the stable temperature difference was observed between the inlet and outlet of the equipment. Fig. 4 presenting the whole process flow of practical work. However, the temperature difference between inlet and outlet has been evaluated at the lowest and highest flow rate of the pump. The flow rate does not have any significant effect on it.

Around $2000 \mathrm{ml}$ nanofluid has been prepared for each type of nanoparticles $\left(\mathrm{Al}_{2} \mathrm{O}_{3}\right.$ and $\left.\mathrm{CNC}\right)$. The volume concentrations were $0.3 \%$ and $0.5 \%$. These four-volume concentrations of 
nanofluids have been loaded in bucket one after another and the lowest flow rate has been set in the pump. This method has been done in a steady-state condition under direct solar radiation.

\section{Result and Discussion}

\subsection{Characterization of Nanofluids}

The size of $\mathrm{Al}_{2} \mathrm{O}_{3}$ nanoparticles was below $80 \mathrm{~nm}$ and most of the particles were spherically determined by using FESEM, as shown in Fig. 5. The elemental composition of nanoparticles was analysed by means of FESEM EDX with $10 \mu \mathrm{m}, 20 \mu \mathrm{m}$, and $60 \mu \mathrm{m}$ electron image. The EDX spectrum shows the presence of aluminium (Al) and oxygen $(\mathrm{O})$ atoms (Fig. 6) and Table 4 depicts the EDX results of the elemental proportion of $\mathrm{Al}_{2} \mathrm{O}_{3}$ nanoparticle with $20 \mu \mathrm{m}$ electron image [49].

In addition, the shape and size of solid nanoparticles into the base fluid that is in nanofluid form can also be measured by TEM image [50] as shown in Fig. 7. Moreover, the dispersion of nanoparticles into the base fluid should be defined precisely. Fig. 7 illustrates that most of the nanoparticles of $\mathrm{Al}_{2} \mathrm{O}_{3}$ nanofluids were nearly spherical and nearly elongated geometry in morphological shape. Nanoparticles were also better uniform in shape and size. The nanoparticles were dispersed evenly into base fluids but often agglomerated into small aggregation.

Apparently, CNC nanoparticles were in gel form and it was not possible to evaluate it morphologically using FESEM. Therefore, CNC nanoparticles have been prepared into two forms such as film and powder to analysis it in FESEM. Fig. 8 shows the morphology of CNC nanoparticles in film form in Fig. 8(a)) and in powder form in Fig. 8(b). The size and shape of nanoparticles could not be measured using FESEM as there were no individual nanosized particles observed in the figure though the samples were dried. Fig. 8 showed the CNC nanoparticles clung with each other. However, the elemental analysis has been done using FESEM EDX. EDX did with $10 \mu \mathrm{m}, 20 \mu \mathrm{m}$ and $60 \mu \mathrm{m}$ electron image similar to $\mathrm{Al}_{2} \mathrm{O}_{3}$ nanoparticles.

The EDX spectrum showed that the clear appearance of carbon $(\mathrm{C})$ and oxygen $(\mathrm{O})$ atoms in CNC nanoparticles as shown in Fig. 9. Besides, Table 5 illustrates the chemical composition of $20 \mu \mathrm{m}$ electron image of CNC nanoparticles with standard deviation [51]. The TEM micrograph of CNC nanoparticles (powder form) and CNC nanofluids showed in Fig. 10 and Fig. 11 respectively. The size and shape of the CNC nanoparticles determined by Fig. 10. In 
this micrographic view, it was observed that the size of the CNC nanoparticles was less than $50 \mathrm{~nm}$. The shape of nanoparticles was in both elongated and nearly spherical geometry. On the other hand, Fig. 11 represents the dispersion phenomenon of CNC nanofluids into the base fluid. The dispersion was not enough fairly even as some aggregation of nanoparticles was obtained due to strong Van der Waals force between the nanoparticles [52].

\subsection{Analysis of Thermo-physical Properties}

\subsubsection{Stability Analysis}

Both qualitative and quantitation method has been applied to evaluate the stability of $\mathrm{Al}_{2} \mathrm{O}_{3}$ and CNC nanofluids. In case of sedimentation observation (Qualitative method), the stability of $\mathrm{Al}_{2} \mathrm{O}_{3}$ and $\mathrm{CNC}$ nanofluids have been examined at various volume concentrations which is similar with Ramachandran, Kadirgama [53] experimental study on effective thermal conductivity and relative viscosity of $\mathrm{CNC} /$ water-EG nanofluids through a combined experimental and statistical approach. The authors evaluated the stability of nanofluids by sedimentation observation. In this study, the observation has been done every day. No aggregation of $\mathrm{Al}_{2} \mathrm{O}_{3}$ and $\mathrm{CNC}$ nanoparticles observed at the bottom of the test tube after one week of nanofluids preparation as shown in Table 6. This observation demonstrates the moderate to good stability of both nanofluids meanwhile the numerical values of stability have been investigated by quantitative methods.

From the quantitative method point of view, measurement of the zeta potential of nanofluids is one of the techniques used to evaluate the stability of nanofluids by analyzing electrophoretic behaviour [54]. The measured value of zeta potential above $30 \mathrm{mV}$ is considered to be a good stable nanofluid [11]. The absolute zeta potential values of all nanofluids are presented in Fig. 12. The highest zeta potential value is about $36.1 \mathrm{mV}$ of $0.3 \% \mathrm{Al}_{2} \mathrm{O}_{3}$ nanofluids followed by $0.5 \% \mathrm{Al}_{2} \mathrm{O}_{3}$ nanofluid with $33.6 \mathrm{mV}$. While $0.1 \%$ and other three-volume concentrations of $\mathrm{CNC}$ nanofluids showed the absolute value of zeta potential is less than $30 \mathrm{mV}$. Meanwhile, the $\mathrm{Al}_{2} \mathrm{O}_{3}$ nanofluids showed positive charge and $\mathrm{CNC}$ exhibited negativity potential behaviour. Long term physical and chemical stability of nanofluids is one of the fundamental requirements for its proper usage in heat transfer applications [54]. Because strong Van der Walls interactions of nanoparticles create clusters/aggregation causing non-homogeneity of nanofluids. Moreover, sedimentation of nanoparticles degrades the thermo-physical properties such as thermal conductivity, density, viscosity, specific heat capacity as stability of nanofluids has a significant effect on thermal conductivity directly or indirectly [55]. Aggregation of 
nanoparticles within the nanofluids can block the tubes which are responsible for discontinuation of heat transfer and resulting deflation of advantages of nanofluids in heat transfer [56].

\subsubsection{Thermal Conductivity Analysis}

The thermal conductivity of the base fluid (60\% water and $40 \% \mathrm{EG}), \mathrm{Al}_{2} \mathrm{O}_{3}$ and $\mathrm{CNC}$ nanofluids with different volume concentrations $(0.1 \%, 0.3 \%$, and $0.5 \%)$ measured at four different temperatures such as $30^{\circ} \mathrm{C}, 50^{\circ} \mathrm{C}, 70^{\circ} \mathrm{C}$, and $80^{\circ} \mathrm{C}$. Thermal conductivity of working fluids increased anomalously due to adding nanoparticles into base fluids and Fig. 13 shows the enhancement of thermal conductivity of nanofluids $\left(\mathrm{Al}_{2} \mathrm{O}_{3}\right.$ and $\left.\mathrm{CNC}\right)$ at $0.1 \%, 0.3 \%$, and $0.5 \%$ volume concentrations. Despite the increment phenomena of thermal conductivity; $0.1 \%$ $\mathrm{CNC}$, nanofluid exhibited a slight decrement of thermal conductivity at a temperature of $50^{\circ} \mathrm{C}$ and $70^{\circ} \mathrm{C}$. However, $\mathrm{Al}_{2} \mathrm{O}_{3}$ exhibited the increment of thermal conductivity consistently. Moreover, the thermal conductivity increases with an increase in temperature as well [33, 34]. Fig. 13 illustrates that the enhancement of thermal conductivity is not linear with linearly increased volume concentration percentage of nanoparticles at any temperature. This similar phenomenon also observed by Wei, Zou [57]. The authors found thermal conductivity enhancement is not even with increased in volume concentration at a temperature of $20^{\circ} \mathrm{C}$. Prior to the experiment with nanofluids, the thermal conductivity of the base fluid (W: EG 60:40) measured to evaluate the measurement accuracy of KD2 Pro Thermal Property Analyser. The error percentage between resulting data and ASHRAE standard of base fluid has been analysed and shown in Fig. 14 which defines the good agreement with the measurement accuracy of the thermal conductivity equipment as well as the thermal conductivity characteristic of the experimental base fluid. The reason for thermal conductivity enhancement can be discussed by the experimental study of Wen and Ding [58]. The authors studied that the nanoparticles in the base fluid increase the thermal conductivity by reducing thermal boundary layer thickness causing convection heat transfer enhancement. Not only that, the migration of nanoparticles in the based fluid is one of the roots of heat transfer enhancement which forms non-uniform distribution of thermal conductivity and viscosity field due to Brownian motion, shear action and spatial gradient in viscosity [59]. 


\subsubsection{Dynamic Viscosity Analysis}

Earlier, the deviation of experimental viscosity data and ASHRAE Standard data of the base fluid has been analysed and presented in Fig. 16. The maximum standard deviation of about 0.27 found at the $80^{\circ} \mathrm{C}$ temperature of the base fluid. The viscosity of nanofluids $\left(\mathrm{Al}_{2} \mathrm{O}_{3}\right.$ and $\mathrm{CNC})$ with different volume concentrations $(0.1 \%, 0.3 \%$, and $0.5 \%)$ determined at four distinct temperatures such as $30^{\circ} \mathrm{C}, 50^{\circ} \mathrm{C}, 70^{\circ} \mathrm{C}$ and $80^{\circ} \mathrm{C}$ as shown in Fig. 15. In this study, viscosity increases with increasing volume fractions of nanoparticles but decreases when the temperature increased, and this phenomenon is similar to many previous studies $[33,34,53]$. The maximum viscosity obtained at $30^{\circ} \mathrm{C}$ of $0.5 \%$ volume concentration $\mathrm{Al}_{2} \mathrm{O}_{3}$ nanofluid whereas $0.3 \%$ volume concentration $\mathrm{CNC}$ nanofluid exhibited the highest viscosity. According to Newtonian Fluid theory, shear stress $(\tau)$ and shear rate $(\gamma)$ are straight and viscosity remains constant as defined Newtonian fluid [60]. In this study, the nanofluids (both $\mathrm{Al}_{2} \mathrm{O}_{3}$ and $\mathrm{CNC}$ ) at various volume concentrations showed the non-Newtonian behaviour as shear viscosity increases with increasing shear stress at every individual temperature.

\subsubsection{Specific Heat Analysis}

The resulting data of specific heat capacity $\left(C_{p}\right)$ of $\mathrm{Al}_{2} \mathrm{O}_{3}$ and $\mathrm{CNC}$ nanofluids (all volume concentrations) are shown in Fig. 17. Insufficient numerical and experimental studies had been conducted to determine the specific heat capacity of nanofluids at different temperature and volume concentrations. O'Hanley, Buongiorno [61] studied the specific heat capacity of nanofluids at various volume concentrations with different types of nanofluids (water-based alumina, silica, copper-oxide). The authors also used a size range (diameter) of nanoparticles. They revealed specific heat capacity decreased due to the crease of volume fractions of nanofluids. Sekhar and Sharma [62] found that the increasing volume concentration of nanofluids (water-based aluminium oxide) decline the specific heat capacity of nanofluids owing to the increase of thermal diffusivity of nanofluids. They also mentioned the increment of temperature causes the decrement of effective specific heat capacity of nanofluids. In this study, the adding of $\mathrm{Al}_{2} \mathrm{O}_{3}$ nanoparticles into the base fluid causes the loss of specific heat capacity and its increases (Fig. 17) with an increase in the mass fraction of nanoparticles into the base fluid [61], whereas $0.5 \% \quad \mathrm{Al}_{2} \mathrm{O}_{3}$ nanofluid showed the negative result at $30^{\circ} \mathrm{C}$ temperature. However, specific heat is an increasing trend due to the increasing temperature of $\mathrm{Al}_{2} \mathrm{O}_{3}$ nanofluid at all volume concentrations [63]. On the other hand, $\mathrm{CNC}$ nanofluids with all volume concentrations at a range of temperatures from $30^{\circ} \mathrm{C}$ to $80^{\circ} \mathrm{C}$ exhibited the negative 
potentiality of specific heat capacity. Moreover, negativity increases with an increasing volume concentration of $\mathrm{CNC}$ nanofluids and with the improvement of temperature as well. In addition, $\mathrm{CNC}$ nanofluids at all volume concentrations showed fewer negativity results at $50^{\circ} \mathrm{C}$ temperature than at $30^{\circ} \mathrm{C}$ temperature. The smaller specific heat of solid particles compared to that of base fluid obviously will decrease the specific heat of the nanofluid mixture. The declining will be continued at the increment of the volumetric loading of particles [64]. Moreover, literature stated, there is good relation between specific heat and thermal conductivity, especially with thermal diffusivity as nanofluids can diffuse heat much better than base fluid such as Vajjha and Das [65] studied that among three of $\left(\mathrm{Al}_{2} \mathrm{O}_{3}, \mathrm{SiO}_{2}, \mathrm{CuO}\right)$ $\mathrm{CuO}$ showed the highest thermal diffusivity at a defined temperature due to it lowest specific heat and high thermal conductivity values.

\subsection{Efficiency Analysis of FPSC}

The inlet and outlet temperature have been monitored several times for individual nanofluids and averaged the data, as shown in Table 7. Fig. 18 and Fig. 19 present the energy gain and efficiency scenario of FPSC. Fig. 18 presents the gradual enhancement of energy gain of $0.3 \%$ $\mathrm{Al}_{2} \mathrm{O}_{3}$ and $0.5 \% \mathrm{Al}_{2} \mathrm{O}_{3}$ nanofluids at a temperature range of $30^{\circ}$ to $80^{\circ} \mathrm{C}$; while $0.3 \% \mathrm{CNC}$ and $0.5 \% \mathrm{CNC}$ nanofluids do not exhibit the linearity of energy gain increment at the same temperature. Both volume concentrations $(0.3 \%$ and $0.5 \%)$ of $\mathrm{CNC}$ shows the decrement of energy gain at $50^{\circ} \mathrm{C}$ temperature. Moreover, the base fluid performs the discontinuation trend of energy gain in this system.

In addition, Fig. 19 illustrates the progressive enhancement of efficiency of $\mathrm{Al}_{2} \mathrm{O}_{3}$ nanofluids (both of $0.3 \%$ and $0.5 \%$ volume con.) whereas $\mathrm{CNC}$ nanofluids at both volume concentrations and base fluid do not maintain the gradual improvement of efficiency of solar collector. Besides, the maximum efficiency of $2.48 \%$ and $8.46 \%$ achieved by $0.5 \% \mathrm{Al}_{2} \mathrm{O}_{3}$ and $0.5 \% \mathrm{CNC}$ at $80^{\circ} \mathrm{C}$ temperature respectively; while there is a big difference between these two values of efficiency. On the other hand, the base fluid shows a maximum efficiency of $1.17 \%$ at $50^{\circ} \mathrm{C}$ temperature.

Currently, there are a few studies conducted with a mixture of water and ethylene glycol (60: 40 ) as the base or working fluid for FPSC. This is due to the stability of nanoparticles in the water-EG mixture. Not all nanofluids stable in water/EG base fluid. It is different compared with water where nanoparticle easily stable specifically $\mathrm{Al}_{2} \mathrm{O}_{3}$ nanoparticles. A comparison 
illustration of efficiency enhancement of FPSC using $\mathrm{Al}_{2} \mathrm{O}_{3}$ and $\mathrm{CNC}$ nonfluids with the experimental study of Meibodi, Kianifar [48] prepared as shown in Table 8. The authors investigated the thermal efficiency of FPSC using $\mathrm{SiO}_{2} /$ water-EG nanofluids with $0 \%, 0.5 \%$, $0.75 \%$ and $1 \%$ volume fraction of nanofluids at three mass flow rates including $0.018,0.032$ and $0.045(\mathrm{~kg} / \mathrm{s})$. They concluded that the enhancement of the thermal efficiency of FPSC was 4 to $8 \%$ in maximum. Moreover, they remarked thermal efficiencies associated with concentrations of $0.75 \%$ and $1 \%$ are very close. The efficiency enhancement of FPSC using $\mathrm{CNC}$ /water-EG is higher than $\mathrm{Al}_{2} \mathrm{O}_{3}$ /water-EG and $\mathrm{SiO}_{2}$ /water-EG nanofluids have been presented in Table 8. Even though the $\mathrm{Al}_{2} \mathrm{O}_{3}$ nanofluids exhibit lower efficiency enhancement, stability of $\mathrm{Al}_{2} \mathrm{O}_{3}$ nanofluids was good.

\section{Conclusion}

In this study, the energy gain and the efficiency of flat plate solar collector enhanced by using $\mathrm{Al}_{2} \mathrm{O}_{3}$ and $\mathrm{CNC}$ nanofluids (at $0.3 \%$ and $0.5 \%$ volume concentrations for both nanofluids) flowing through inside the tubes (header and riser) under direct solar radiation. Nanofluids play the role of working fluids. Therefore, findings of the works done throughout the study can be concluded as follows,

- $\quad 0.3 \%$ and $0.5 \% \mathrm{Al}_{2} \mathrm{O}_{3}$ nanofluids performed good stability while $0.1 \% \mathrm{Al}_{2} \mathrm{O}_{3}$ showed moderate stability. On the other hand, CNC nanofluids (all volume concentrations) exhibited the initial stage of instability.

- Maximum enhancement of thermal conductivity was $11.5 \%$ and $13.4 \%$ for CNC and $\mathrm{Al}_{2} \mathrm{O}_{3}$ nanofluids respectively at $80^{\circ} \mathrm{C}$ temperature.

- Dynamic viscosity of $\mathrm{Al}_{2} \mathrm{O}_{3}$ nanofluids (all volume con.) was decreasing and at $80^{\circ} \mathrm{C}$ temperature showed the lowest value of it, while CNC nanofluids (all volume fractions) show the decreasing trend of dynamic viscosity until at $70^{\circ} \mathrm{C}$ temperature. $0.5 \% \mathrm{Al}_{2} \mathrm{O}_{3}$ nanofluid performed the lowest increment of the viscosity of about $4.9 \%$ at $80^{\circ} \mathrm{C}$ temperature whereas it was in maximal of $57 \%$ at $30^{\circ} \mathrm{C}$ temperature than the base fluid.

- Specific heat decreases with increasing nanofluids volume concentrations, but it is improved with the improvement of temperature. Moreover, $\mathrm{CNC}$ showed negative specific heat capacity which defines the mechanical instability that means the isothermal compressibility is negative or equivalent [66].

- Experimental data reveal that the outlet temperature enhanced by nanofluids and maximum increased by $0.5 \% \mathrm{Al}_{2} \mathrm{O}_{3}$ nanofluid of about $4.4 \%$. 
- Energy gain and efficiency of flat plate solar collector improved too. Maximum efficiency of flat plate solar collector obtained of around $2.48 \%$ for $0.5 \% \mathrm{Al}_{2} \mathrm{O}_{3}$ and $8.46 \%$ for $0.5 \%$ CNC nanofluids. Thus, about $5.8 \%$ efficiency can be improved using $\mathrm{CNC} /$ water-EG nanofluid in a flat plate solar collector.

\section{Acknowledgment}

The authors would like to acknowledge to University Malaysia Pahang (UMP), Ministry of Higher Education (MOHE) of Malaysia for the Research Grants RDU 190323 and Bangabandhu Science and Technology Fellowship Trust (Bangladesh) for the financial support and laboratory facilities provided by them throughout this study. Doctoral Fellowship Scheme conferred to Kaniz Farhana by the Ministry of Science and Technology (Bangladesh) is also greatly appreciated.

R. Saidur would like to acknowledge the financial support provided by the Sunway University through the project no. STR-RCTR-RCNMET-001-2019.

\section{References}

1. Viral, R. and D. Khatod, Optimal planning of distributed generation systems in distribution system: A review. Renewable and Sustainable Energy Reviews, 2012. 16(7): p. 5146-5165.

2. Bell, S., et al., Sociality and electricity in the United Kingdom: the influence of household dynamics on everyday consumption. Energy research \& social science, 2015. 9: p. 98-106.

3. Gadisa, A., et al., Transparent polymer cathode for organic photovoltaic devices. Synthetic metals, 2006. 156(16): p. 1102-1107.

4. Renewable Energy Policy Network, The first decade : 2004 - 2014:10 years of renewable energy progress; Renewable energy policy Network For the 21st Century, France. 2014.

5. Hussein, A.K., Applications of nanotechnology to improve the performance of solar collectors-Recent advances and overview. Renewable and Sustainable Energy Reviews, 2016. 62: p. 767-792.

6. Alim, M., et al., Analyses of entropy generation and pressure drop for a conventional flat plate solar collector using different types of metal oxide nanofluids. Energy and Buildings, 2013. 66: p. 289-296.

7. Struckmann, F., Analysis of a flat-plate solar collector (Report no. 2008MVK160). Heat and Mass Transport., 2008.

8. Muhammad, M.J., et al., Thermal performance enhancement of flat-plate and evacuated tube solar collectors using nanofluid: A review. International Communications in Heat and Mass Transfer, 2016. 76: p. 6-15.

9. Bashirnezhad, K., M. Ghavami, and A.A. Alrashed, Experimental investigations of nanofluids convective heat transfer in different flow regimes: A review. Journal of Molecular Liquids, 2017. 244: p. 309-321.

10. Chol, S., Enhancing thermal conductivity of fluids with nanoparticles. ASME-Publications-Fed, 1995. 231: p. 99-106.

11. Yu, W. and H. Xie, A review on nanofluids: preparation, stability mechanisms, and applications. Journal of Nanomaterials, 2012. 2012: p. 1.

12. Feynman, R.P., There's plenty of room at the bottom. Resonance-Heidelberg, 2011. 16(9): $p$. 890.

13. Hayat, T., et al., Magnetohydrodynamic three-dimensional flow of viscoelastic nanofluid in the presence of nonlinear thermal radiation. Journal of Magnetism and Magnetic Materials, 2015. 385: p. 222-229. 
14. Ganvir, R., P. Walke, and V. Kriplani, Heat transfer characteristics in nanofluid-A review. Renewable and Sustainable Energy Reviews, 2016.

15. Ghanbarpour, M., et al., Improvement of heat transfer characteristics of cylindrical heat pipe by using SiC nanofluids. Applied Thermal Engineering, 2015. 90: p. 127-135.

16. Sara, O., et al., Effect of suspended CuO nanoparticles on mass transfer to a rotating disc electrode. Experimental Thermal and Fluid Science, 2011. 35(3): p. 558-564.

17. Nagarajan, P., et al., Nanofluids for solar collector applications: a review. Energy Procedia, 2014. 61: p. 2416-2434.

18. Panchal, K., Nanofluid: A tool to increase the efficiency of solar collector. International Journal for InnovativeEngineering and Technology, 2015. 5(2): p. 350-366.

19. Abitbol, T., et al., Nanocellulose, a tiny fiber with huge applications. Current opinion in biotechnology, 2016. 39: p. 76-88.

20. Theivasanthi, T., et al., Synthesis and characterization of cotton fiber-based nanocellulose. International journal of biological macromolecules, 2017.

21. Yousefi, T., et al., An experimental investigation on the effect of MWCNT- $\mathrm{H}_{2} \mathrm{O}$ nanofluid on the efficiency of flat-plate solar collectors. Experimental Thermal and Fluid Science, 2012. 39: p. 207-212.

22. Moghadam, A.J., et al., Effects of CuO/water nanofluid on the efficiency of a flat-plate solar collector. Experimental Thermal and Fluid Science, 2014. 58: p. 9-14.

23. Said, Z., et al., Performance enhancement of a flat plate solar collector using titanium dioxide nanofluid and polyethylene glycol dispersant. Journal of Cleaner Production, 2015. 92: p. 343-353.

24. Verma, S.K., A.K. Tiwari, and D.S. Chauhan, Performance augmentation in flat plate solar collector using MgO/water nanofluid. Energy Conversion and Management, 2016. 124: p. 607-617.

25. Verma, S.K., A.K. Tiwari, and D.S. Chauhan, Experimental evaluation of flat plate solar collector using nanofluids. Energy Conversion and Management, 2017. 134: p. 103-115.

26. Ziyadanogullari, N.B., H. Yucel, and C. Yildiz, Thermal performance enhancement of flat-plate solar collectors by means of three different nanofluids. Thermal Science and Engineering Progress, 2018. 8: p. 55-65.

27. Eltaweel, M. and A.A. Abdel-Rehim, Energy and exergy analysis of a thermosiphon and forced-circulation flat-plate solar collector using MWCNT/Water nanofluid. Case Studies in Thermal Engineering, 2019. 14: p. 100416.

28. Gaos, Y.S., et al. The performance of solar collector CPC (compound parabolic concentrator) type with three pipes covered by glass tubes. in AIP Conference Proceedings. 2017. AIP Publishing.

29. Suresh, S., et al., Synthesis of Al 20 3-Cu/water hybrid nanofluids using two step method and its thermo physical properties. Colloids and Surfaces A: Physicochemical and Engineering Aspects, 2011. 388(1): p. 41-48.

30. Wei, B., et al., Thermo-physical property evaluation of diathermic oil based hybrid nanofluids for heat transfer applications. International Journal of Heat and Mass Transfer, 2017. 107: p. 281-287.

31. Baghbanzadeh, M., et al., Synthesis of spherical silica/multiwall carbon nanotubes hybrid nanostructures and investigation of thermal conductivity of related nanofluids. Thermochimica acta, 2012. 549: p. 87-94.

32. Nikkam, N., et al., Fabrication, characterization and thermophysical property evaluation of SiC nanofluids for heat transfer applications. Nano-Micro Letters, 2014. 6(2): p. 178-189.

33. Ramachandran, K., et al., Thermophysical properties measurement of nano cellulose in ethylene glycol/water. Applied Thermal Engineering, 2017. 123: p. 1158-1165. 
34. Azmi, W., et al., Heat transfer and friction factor of water and ethylene glycol mixture based $\mathrm{TiO}_{2}$ and $\mathrm{Al}_{2} \mathrm{O}_{3}$ nanofluids under turbulent flow. International Communications in Heat and Mass Transfer, 2016. 76: p. 24-32.

35. Sundar, L.S., et al., Nanodiamond-Fe304 nanofluids: preparation and measurement of viscosity, electrical and thermal conductivities. International Communications in Heat and Mass Transfer, 2016. 73: p. 62-74.

36. Abbasi, S.M., et al., The effect of functionalisation method on the stability and the thermal conductivity of nanofluid hybrids of carbon nanotubes/gamma alumina. Ceramics International, 2013. 39(4): p. 3885-3891.

37. Agarwal, R., et al., Synthesis, characterization, thermal conductivity and sensitivity of CuO nanofluids. Applied Thermal Engineering, 2016. 102: p. 1024-1036.

38. Kadirgama, K., et al., Thermal analysis of SUS 304 stainless steel using ethylene glycol/nanocellulose-based nanofluid coolant. The International Journal of Advanced Manufacturing Technology, 2018. 97(5-8): p. 2061-2076.

39. Azmi, W., et al., Heat transfer and friction factor of water based $\mathrm{TiO}_{2}$ and $\mathrm{SiO}_{2}$ nanofluids under turbulent flow in a tube. International Communications in Heat and Mass Transfer, 2014. 59: p. 30-38.

40. Esfe, M.H., et al., Experimental determination of thermal conductivity and dynamic viscosity of $\mathrm{Ag}-\mathrm{MgO} /$ water hybrid nanofluid. International Communications in Heat and Mass Transfer, 2015. 66: p. 189-195.

41. Samylingam, L., et al., Thermal analysis of cellulose nanocrystal-ethylene glycol nanofluid coolant. International Journal of Heat and Mass Transfer, 2018. 127: p. 173-181.

42. Chiam, $\mathrm{H}$., et al., Thermal conductivity and viscosity of $\mathrm{Al}_{2} \mathrm{O}_{3}$ nanofluids for different based ratio of water and ethylene glycol mixture. Experimental Thermal and Fluid Science, 2017. 81: p. 420-429.

43. Sun, Z., T. Deluca, and K. Mattison, The size and rheology characterization of concentrated emulsions. American laboratory, 2005. 37(12): p. 8.

44. Kodre, K., et al., Differential scanning calorimetry: A review. Research and Reviews: Journal of Pharmaceutical Analysis, 2014. 3(3): p. 11-22.

45. O'neill, M., Measurement of specific heat functions by differential scanning calorimetry. Analytical chemistry, 1966. 38(10): p. 1331-1336.

46. Demetzos, C., Differential scanning calorimetry (DSC): a tool to study the thermal behavior of lipid bilayers and liposomal stability. Journal of liposome research, 2008. 18(3): p. 159-173.

47. Clas, S.-D., C.R. Dalton, and B.C. Hancock, Differential scanning calorimetry: applications in drug development. Pharmaceutical science \& technology today, 1999. 2(8): p. 311-320.

48. Meibodi, S.S., et al., Experimental investigation on the thermal efficiency and performance characteristics of a flat plate solar collector using $\mathrm{SiO}_{2} / \mathrm{EG}$-water nanofluids. International Communications in Heat and Mass Transfer, 2015. 65: p. 71-75.

49. Gupta, M., V. Singh, and P. Katyal, Synthesis and structural characterization of $\mathrm{Al}_{2} \mathrm{O}_{3}$ nanofluids. Materials Today: Proceedings, 2018. 5(14): p. 27989-27997.

50. Abdul Wahab, et al., Solar energy systems - Potential of nanofluids. Journal of Molecular Liquids 2019.

51. Awang, N., et al., An experimental study on characterization and properties of nano lubricant containing Cellulose Nanocrystal (CNC). International Journal of Heat and Mass Transfer, 2019. 130: p. 1163-1169.

52. Rance, G.A., et al., van der Waals interactions between nanotubes and nanoparticles for controlled assembly of composite nanostructures. ACS nano, 2010. 4(8): p. 4920-4928.

53. Ramachandran, K., et al., Investigation on effective thermal conductivity and relative viscosity of cellulose nanocrystal as a nanofluidic thermal transport through a combined experimental-Statistical approach by using Response Surface Methodology. Applied Thermal Engineering, 2017. 122: p. 473-483. 
54. Ghadimi, A., R. Saidur, and H. Metselaar, A review of nanofluid stability properties and characterization in stationary conditions. International Journal of Heat and Mass Transfer, 2011. 54(17): p. 4051-4068.

55. Korada, V.S. and N.H. Hamid, Engineering Applications of Nanotechnology: From Energy to Drug Delivery. 2017: Springer.

56. Sharma, S. and S.M. Gupta, Preparation and evaluation of stable nanofluids for heat transfer application: a review. Experimental Thermal and Fluid Science, 2016. 79: p. 202-212.

57. Wei, B., C. Zou, and X. Li, Experimental investigation on stability and thermal conductivity of diathermic oil based TiO 2 nanofluids. International Journal of Heat and Mass Transfer, 2017. 104: p. 537-543.

58. Wen, D. and Y. Ding, Experimental investigation into convective heat transfer of nanofluids at the entrance region under laminar flow conditions. International journal of heat and mass transfer, 2004. 47(24): p. 5181-5188.

59. Ding, Y. and D. Wen, Particle migration in a flow of nanoparticle suspensions. Powder Technology, 2005. 149(2-3): p. 84-92.

60. Bagnold, R.A., Experiments on a gravity-free dispersion of large solid spheres in a Newtonian fluid under shear. Proceedings of the Royal Society of London. Series A. Mathematical and Physical Sciences, 1954. 225(1160): p. 49-63.

61. O'Hanley, H., et al., Measurement and model validation of nanofluid specific heat capacity with differential scanning calorimetry. Advances in Mechanical Engineering, 2012. 4: p. 181079.

62. Sekhar, Y.R. and K. Sharma, Study of viscosity and specific heat capacity characteristics of water-based $\mathrm{Al}_{2} \mathrm{O}_{3}$ nanofluids at low particle concentrations. Journal of experimental Nanoscience, 2015. 10(2): p. 86-102.

63. Singh, R.K., et al., Experimental investigation of thermal conductivity and specific heat of nanoparticles mixed cutting fluids. Materials Today: Proceedings, 2017. 4(8): p. 8587-8596.

64. Murshed, S.S., Simultaneous measurement of thermal conductivity, thermal diffusivity, and specific heat of nanofluids. Heat Transfer Engineering, 2012. 33(8): p. 722-731.

65. Vajjha, R.S. and D.K. Das, A review and analysis on influence of temperature and concentration of nanofluids on thermophysical properties, heat transfer and pumping power. International Journal of Heat and Mass Transfer, 2012. 55(15-16): p. 4063-4078.

66. Das, C., S.D. Gupta, and A. Mekjian, Negative specific heat in a thermodynamic model of multifragmentation. Physical Review C, 2003. 68(1): p. 014607. 


\section{List of Figures}

Fig. 1. Preparation process of nanofluids.

Fig. 2. Specific heat measurement equipment (a) DSC Linseis 1000 (b) electric balance, and (c) aluminium crucible.

Fig. 3. The experimental setup.

Fig. 4. Process flow of the experimental work.

Fig. 5. FESEM morphology of $\mathrm{Al}_{2} \mathrm{O}_{3}$ nanoparticles (Magnification x70,000; WD 9.9 $\mathrm{mm})$.

Fig. 6. EDX spectrum of $\mathrm{Al}_{2} \mathrm{O}_{3}$ nanoparticles.

Fig. 7. TEM morphology of $\mathrm{Al}_{2} \mathrm{O}_{3}$ nanofluids (Magnification x100,000).

Fig. 8. FESEM micrograph of CNC nanoparticles (a) film form (Magnification x70,000; WD $9.3 \mathrm{~mm}$ ) and (b) powder form (Magnification x70,000; WD $9.4 \mathrm{~mm}$ ).

Fig. 9. EDX micrograph of CNC nanoparticles.

Fig. 10. TEM image of CNC nanoparticles (Magnification x62,000).

Fig. 11. TEM morphology of CNC nanofluids (Magnification x50,000).

Fig. 12. Quantitative analysis of the stability of nanofluids.

Fig. 13. Thermal conductivity of $\mathrm{Al}_{2} \mathrm{O}_{3}$ and $\mathrm{CNC}$ nanofluids at various temperatures.

Fig. 14. Graphical presentation of error difference of thermal conductivity of experimental and ASHRAE Standard data of base fluid.

Fig. 15. Temperature dependence of viscosity of $\mathrm{Al}_{2} \mathrm{O}_{3}$ and $\mathrm{CNC}$ nanofluids.

Fig. 16. Variation of error of dynamic viscosity of experimental and ASHRAE Standard data of base fluid.

Fig. 17. Evaluation of specific heat of $\mathrm{Al}_{2} \mathrm{O}_{3}$ and $\mathrm{CNC}$ nanofluids correlated with temperature.

Fig. 18. Energy gain of flat plate solar collector.

Fig. 19. Improvement of efficiency of flat plate solar collector. 


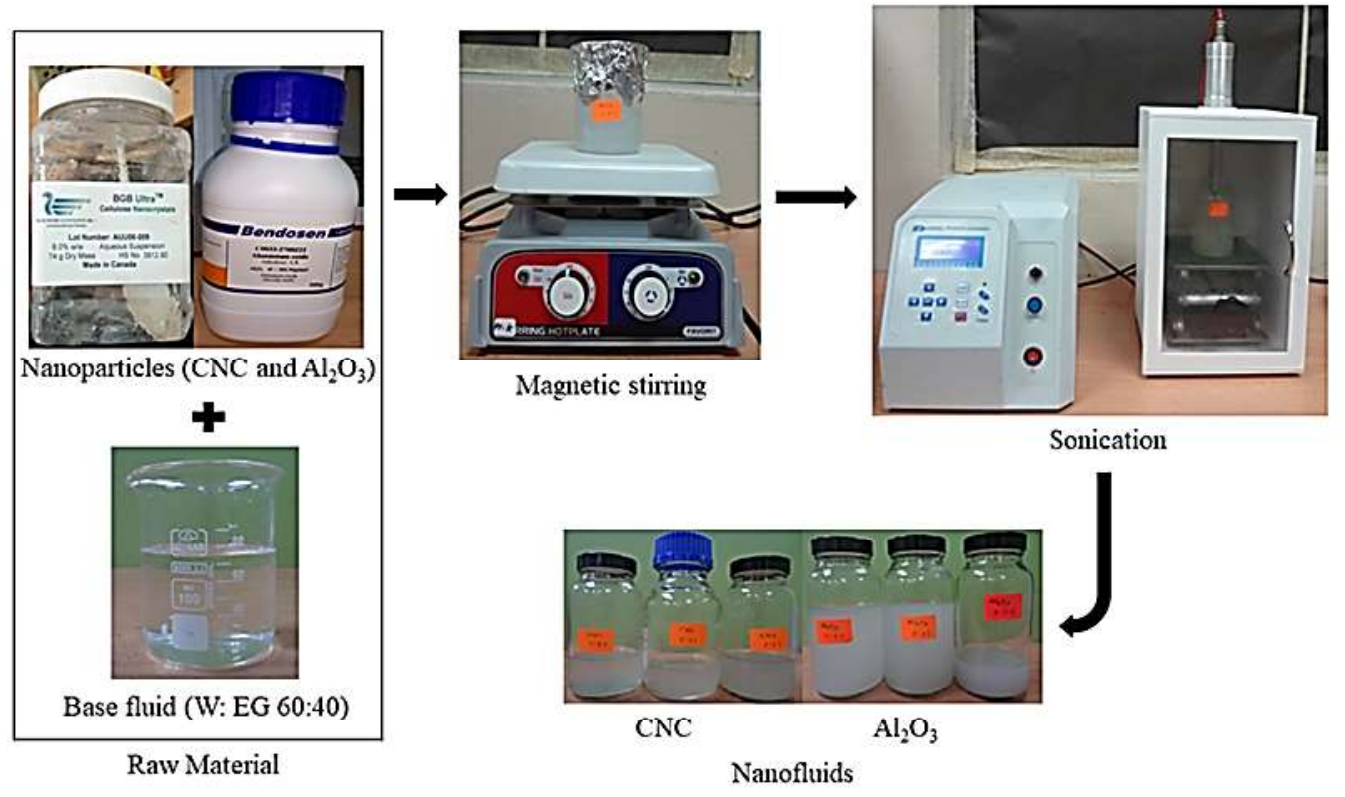

Fig. 1. Preparation process of nanofluids. 


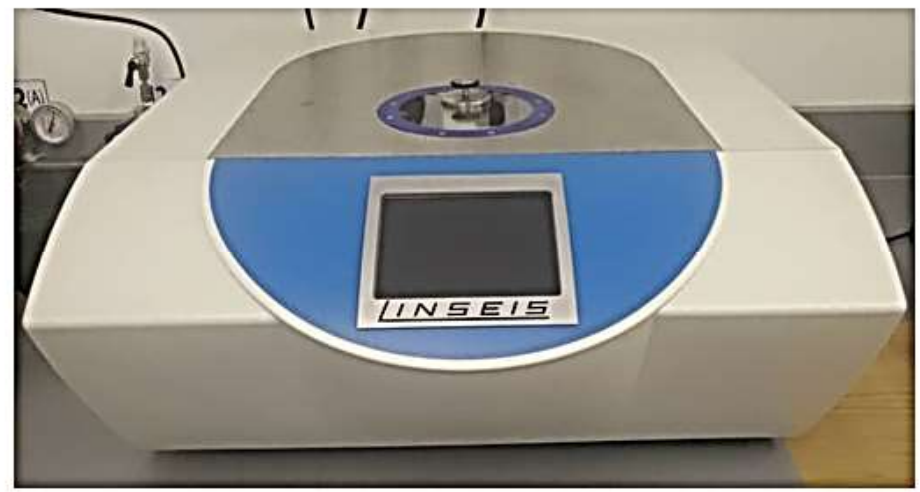

(a)
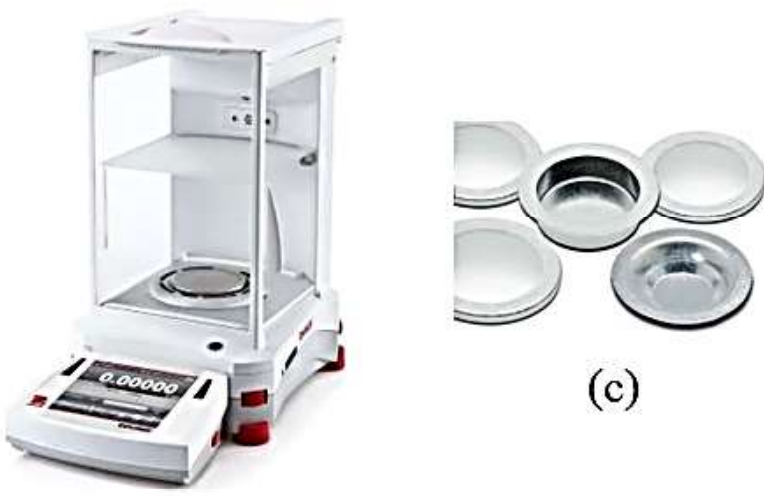

(c)

(b)

Fig. 2. Specific heat measurement equipment (a) DSC Linseis 1000 (b) electric balance, and (c) aluminium crucible. 


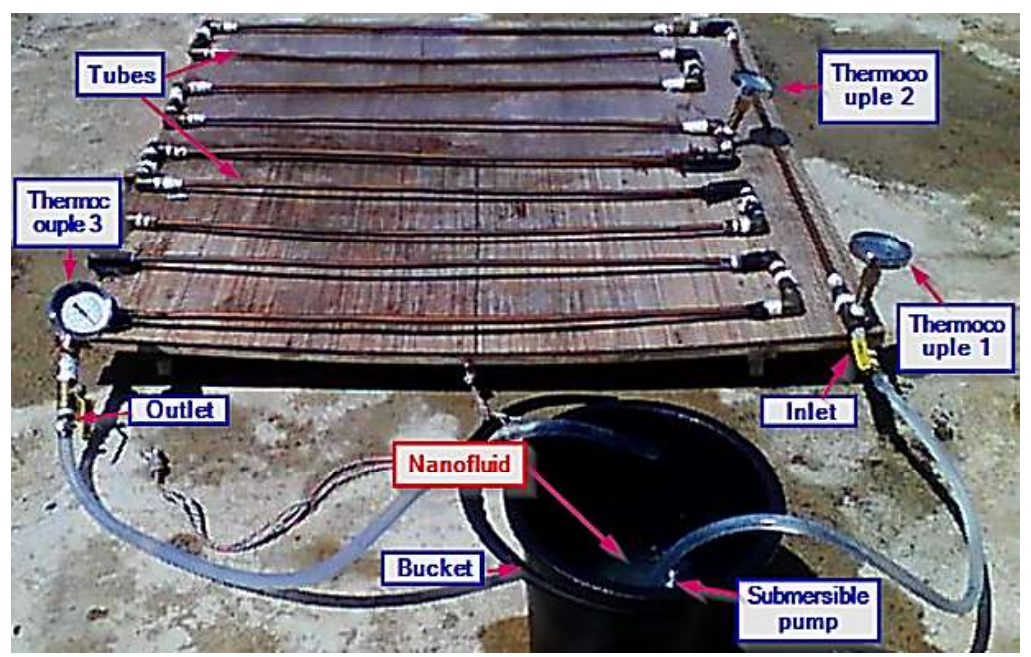

Fig. 3. The experimental setup. 


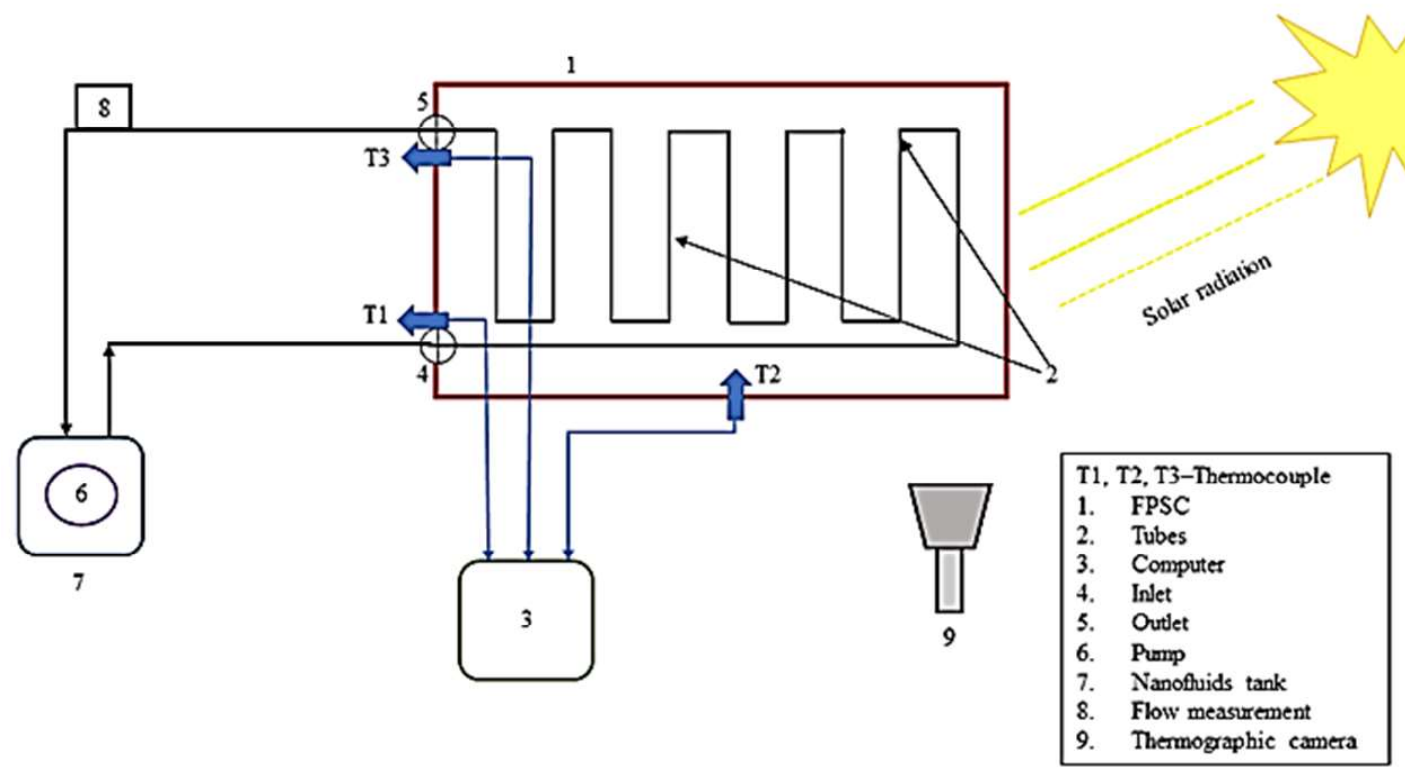

Fig. 4. Process flow of the experimental work. 


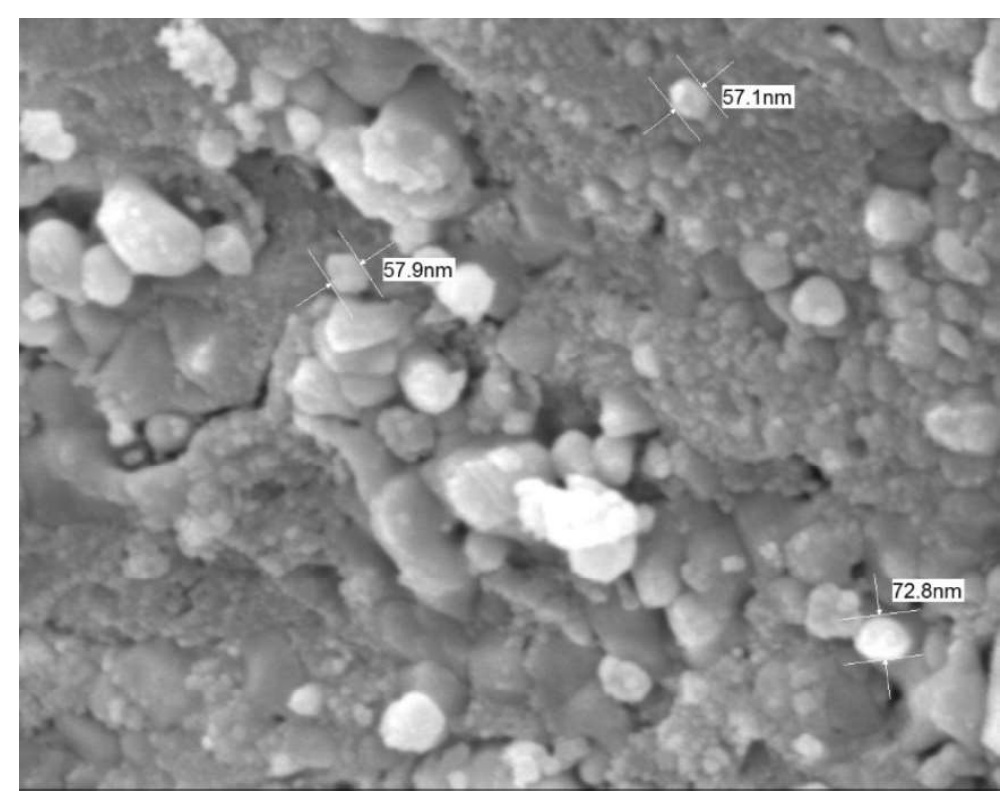

Fig. 5. FESEM morphology of $\mathrm{Al}_{2} \mathrm{O}_{3}$ nanoparticles (Magnification x70,000; WD $9.9 \mathrm{~mm}$ ). 


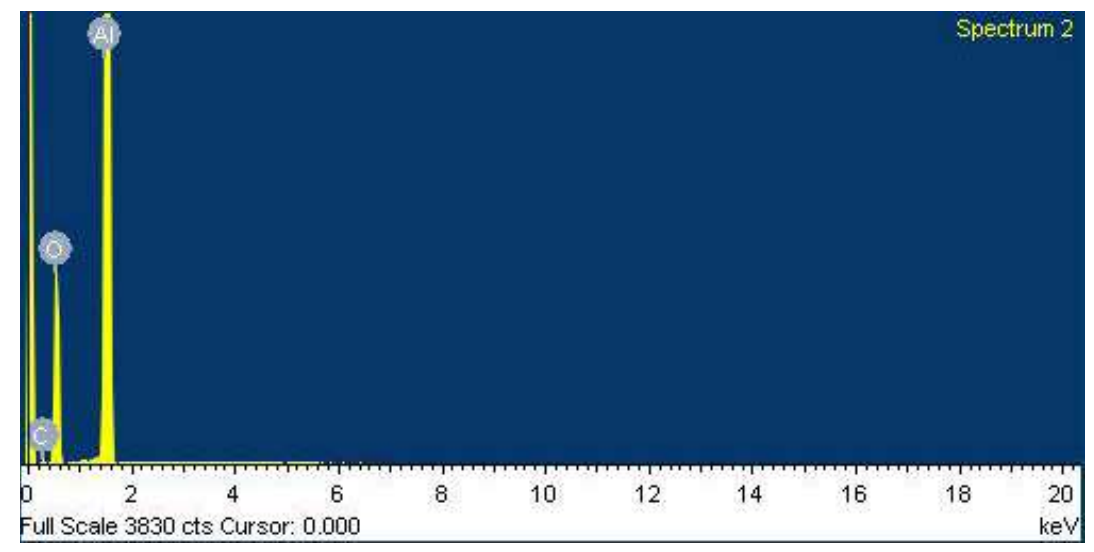

Fig. 6. EDX spectrum of $\mathrm{Al}_{2} \mathrm{O}_{3}$ nanoparticles. 


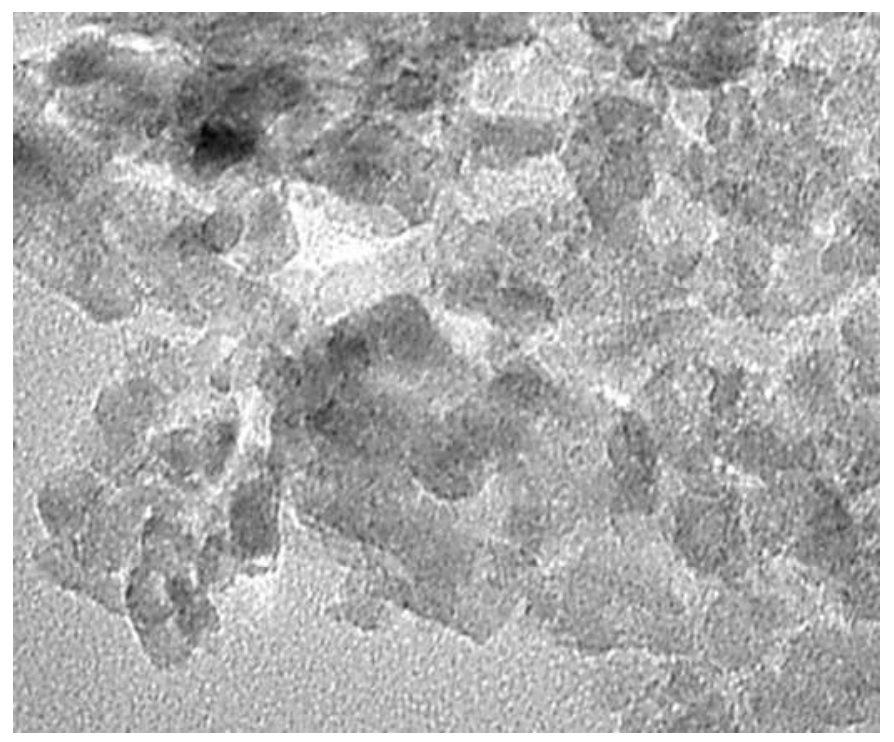

Fig. 7. TEM morphology of $\mathrm{Al}_{2} \mathrm{O}_{3}$ nanofluids (Magnification $\mathrm{x} 100,000$ ). 


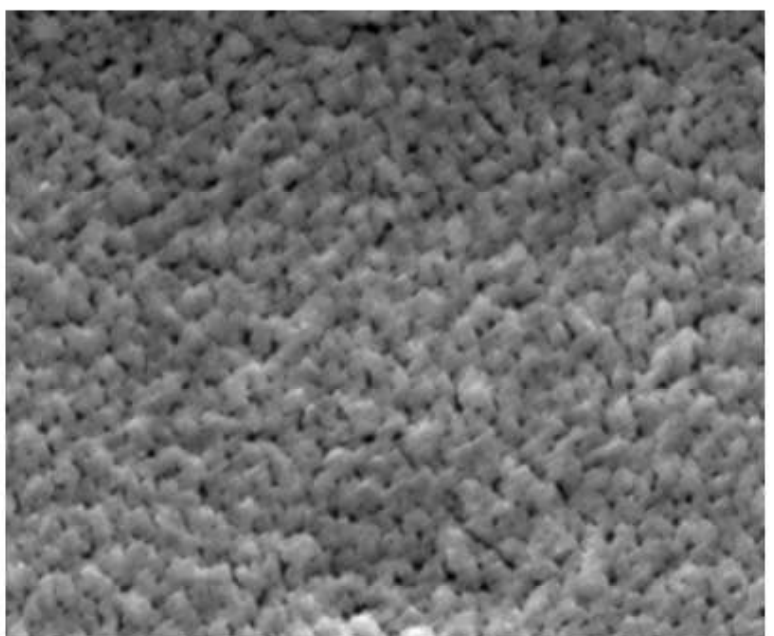

(a)

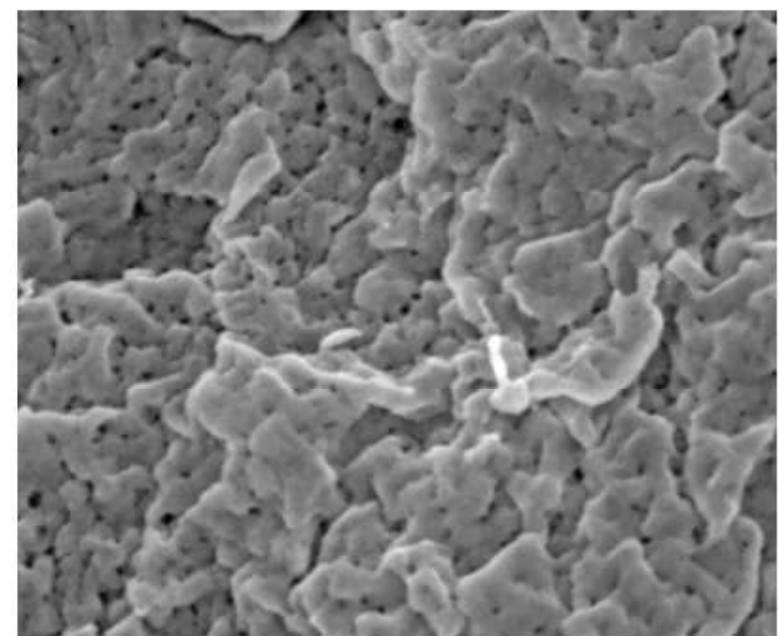

(b)

Fig. 8. FESEM micrograph of CNC nanoparticles (a) film form (Magnification x70,000; WD $9.3 \mathrm{~mm}$ ) and (b) powder form (Magnification x70,000; WD $9.4 \mathrm{~mm}$ ). 


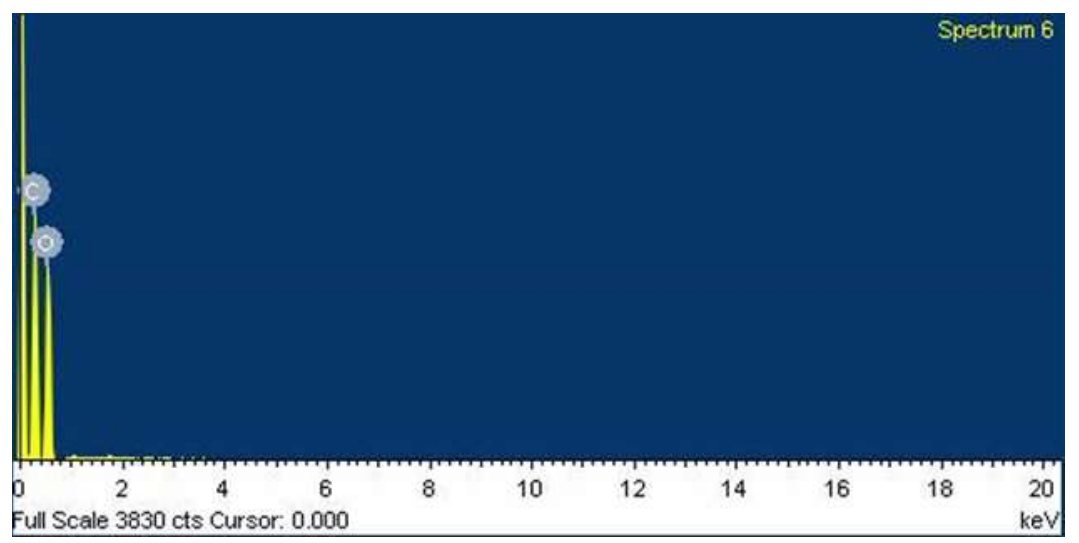

Fig. 9. EDX micrograph of $\mathrm{CNC}$ nanoparticles. 


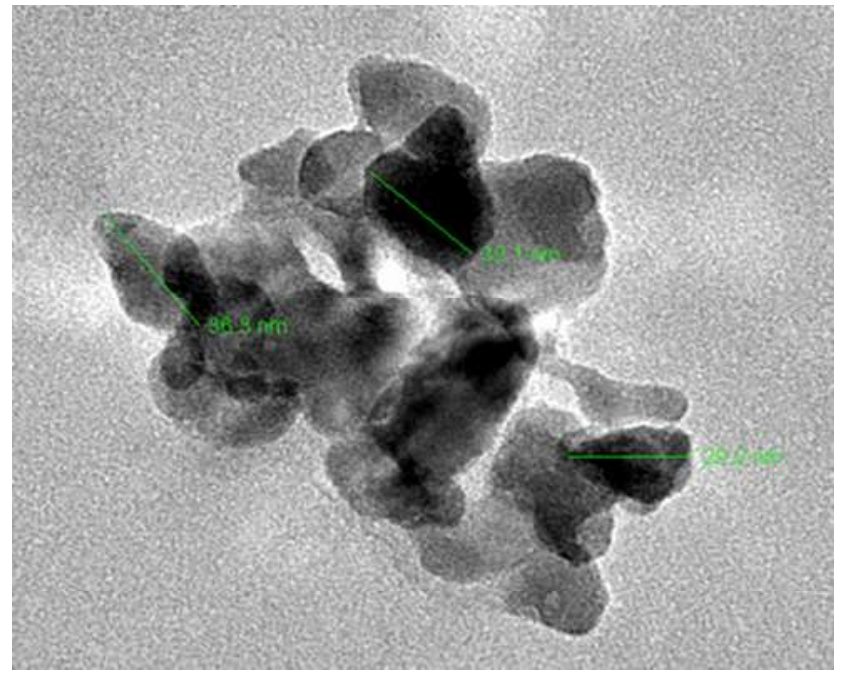

Fig. 10. TEM image of CNC nanoparticles (Magnification x62,000). 


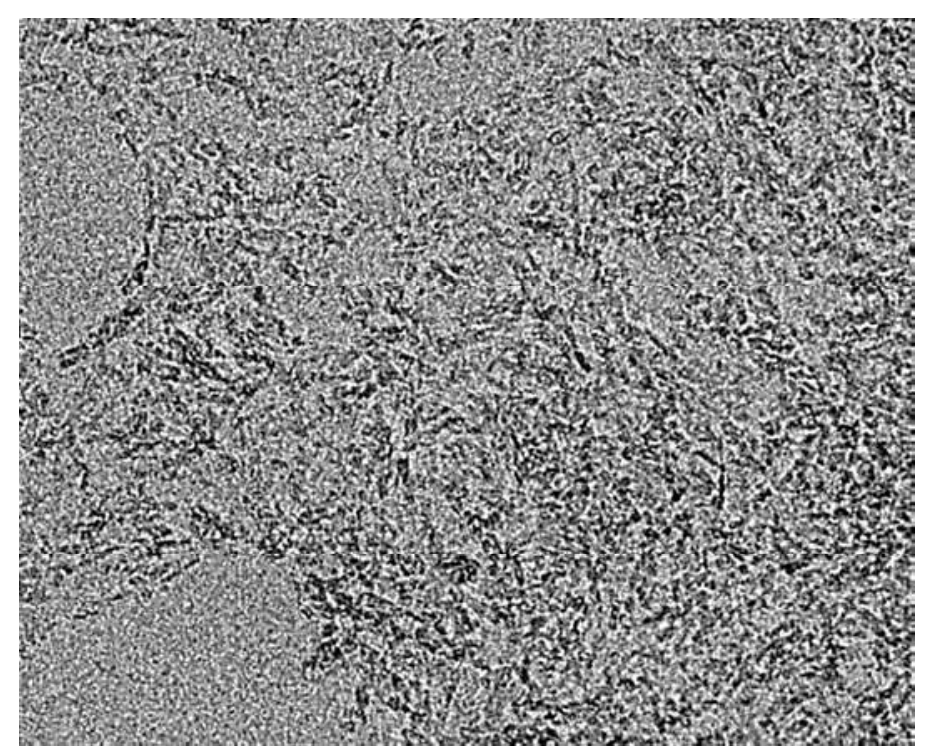

Fig. 11. TEM morphology of CNC nanofluids (Magnification x50,000). 


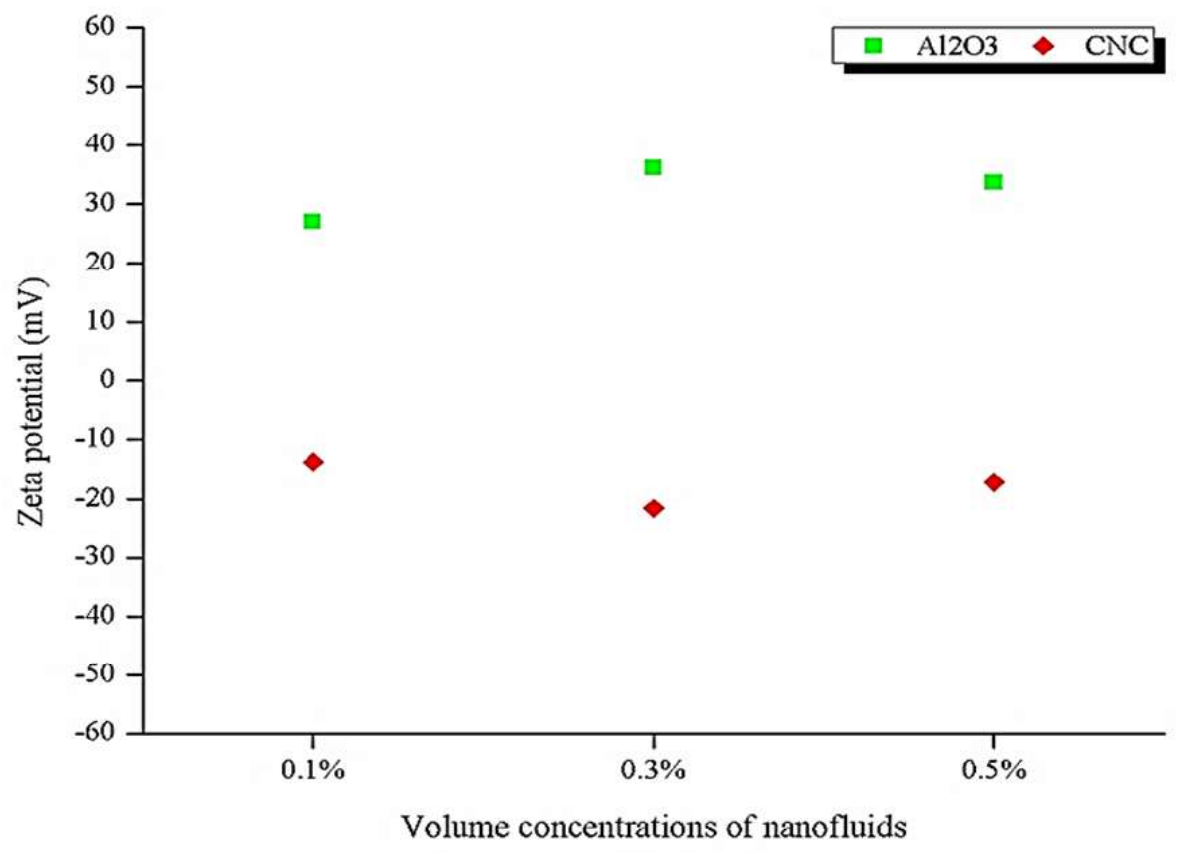

Fig. 12. Quantitative analysis of the stability of nanofluids. 


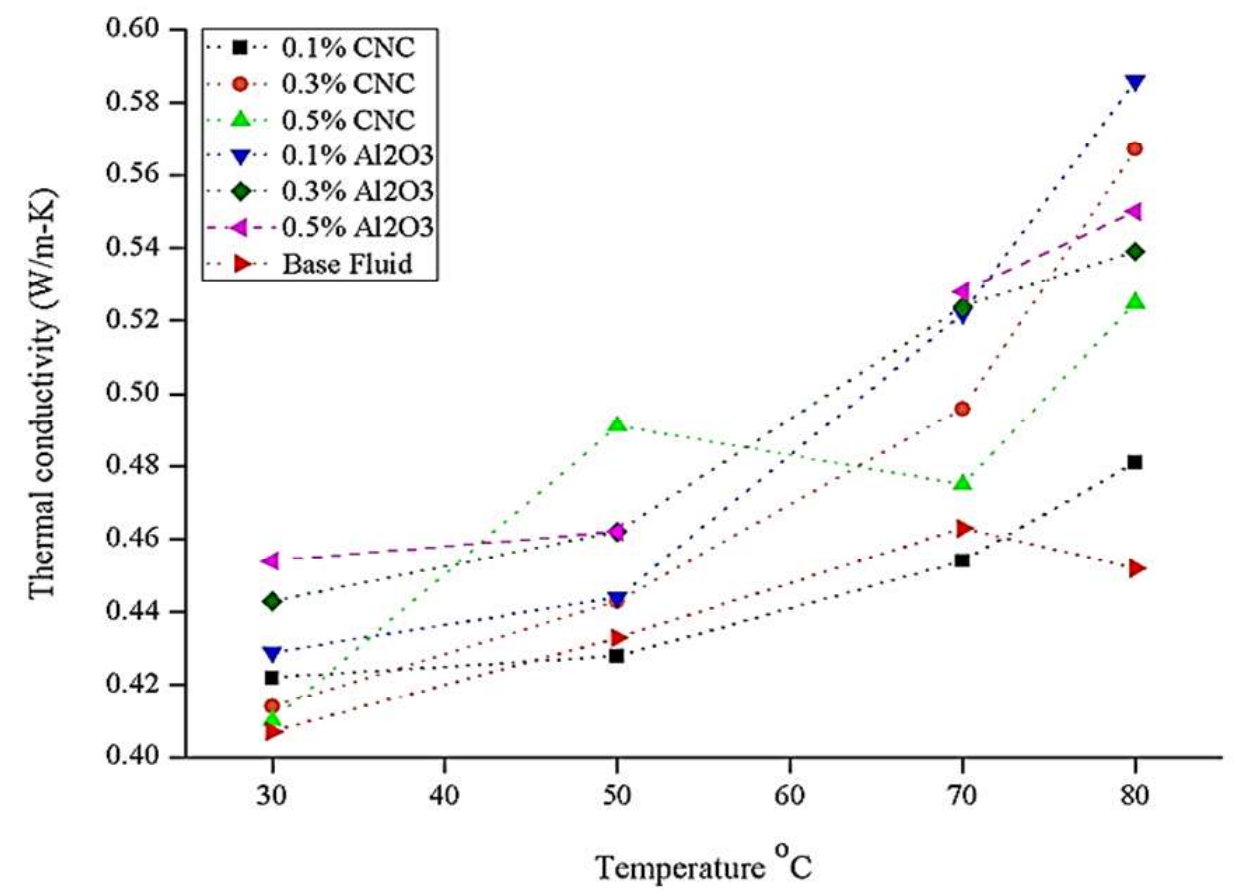

Fig. 13. Thermal conductivity of $\mathrm{Al}_{2} \mathrm{O}_{3}$ and $\mathrm{CNC}$ nanofluids at various temperatures. 


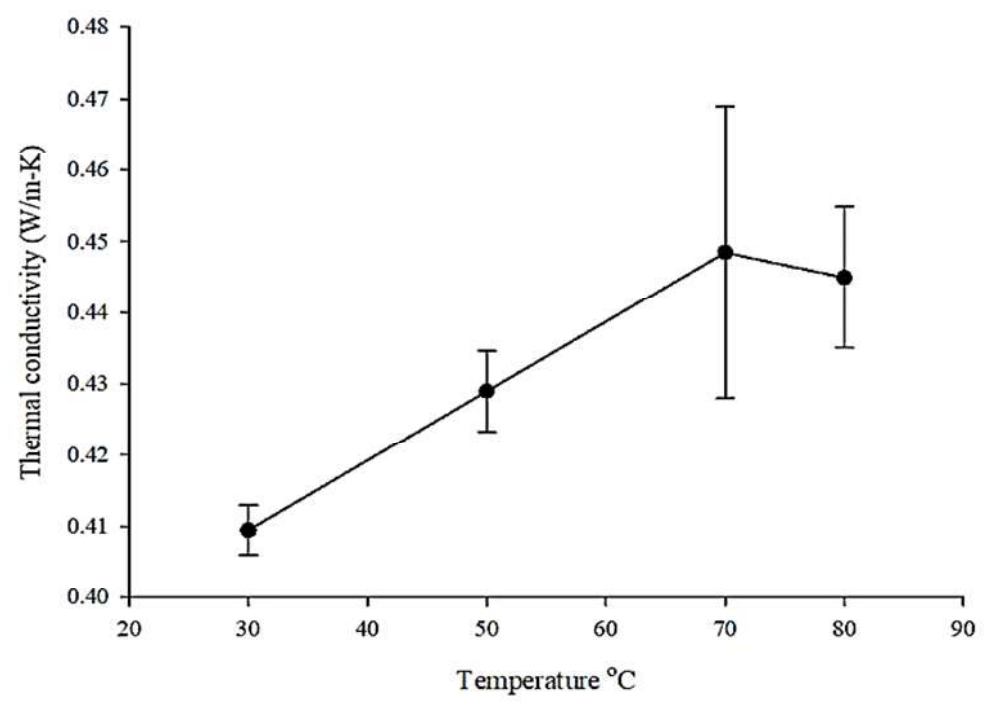

Fig. 14. Graphical presentation of error difference of thermal conductivity of experimental and ASHRAE Standard data of base fluid. 


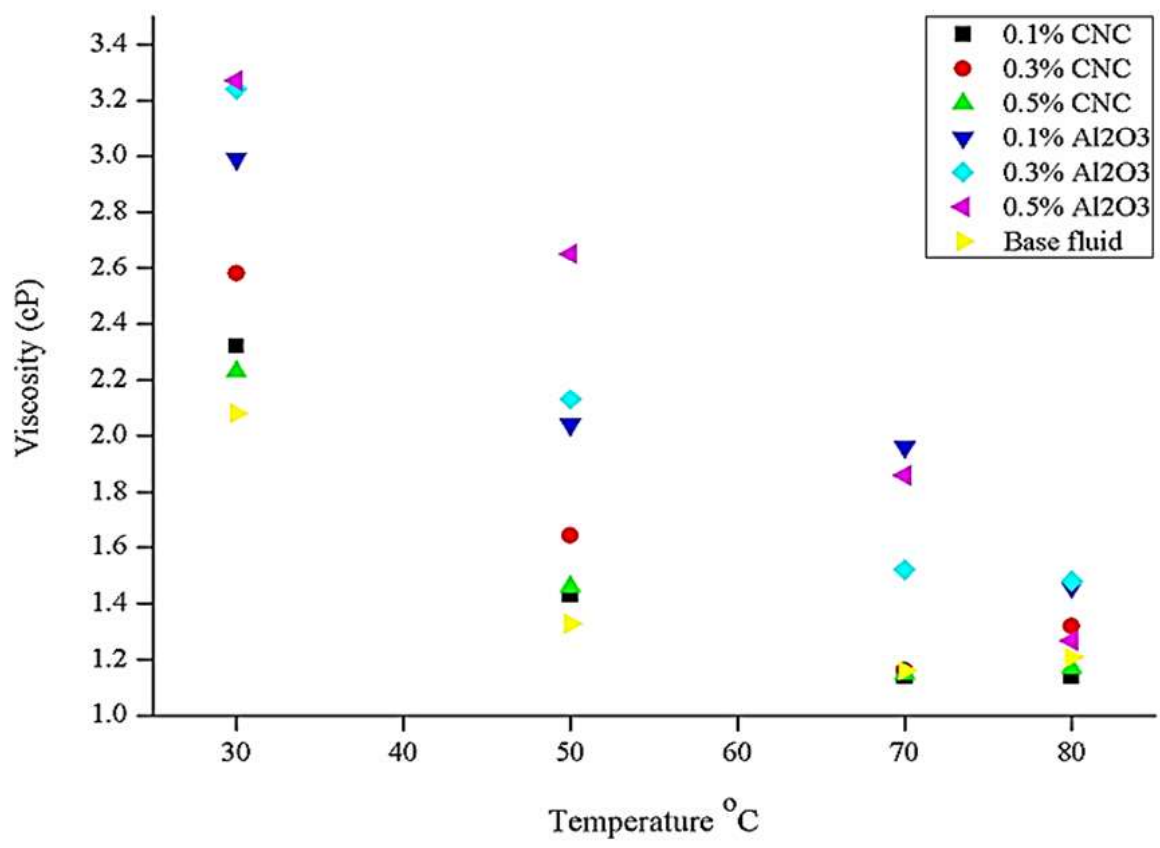

Fig. 15. Temperature dependence of viscosity of $\mathrm{Al}_{2} \mathrm{O}_{3}$ and $\mathrm{CNC}$ nanofluids. 


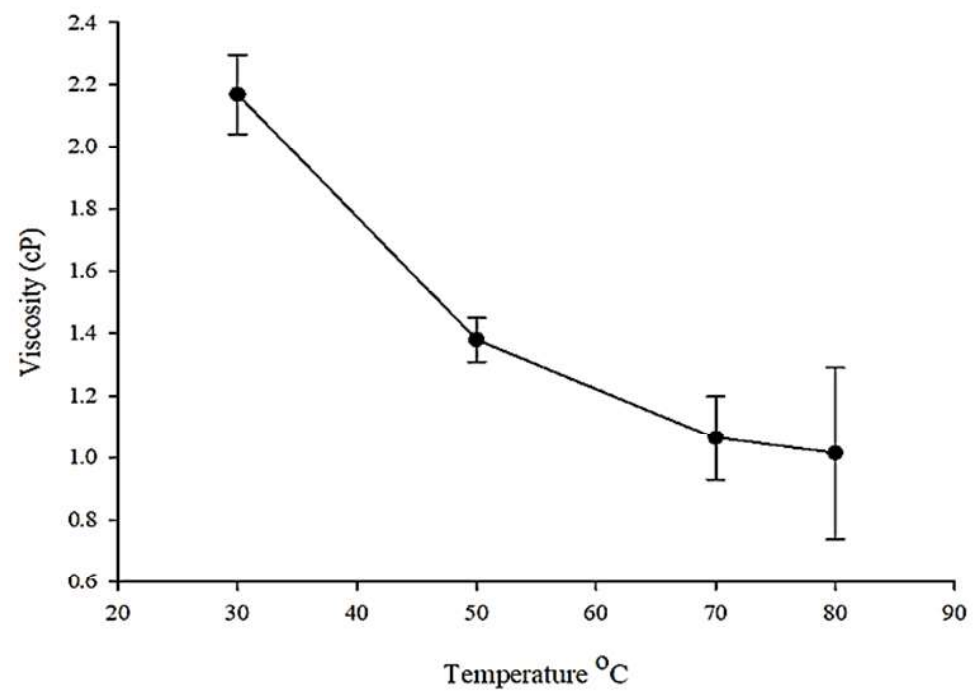

Fig. 16. Variation of error of dynamic viscosity of experimental and ASHRAE Standard data of base fluid. 


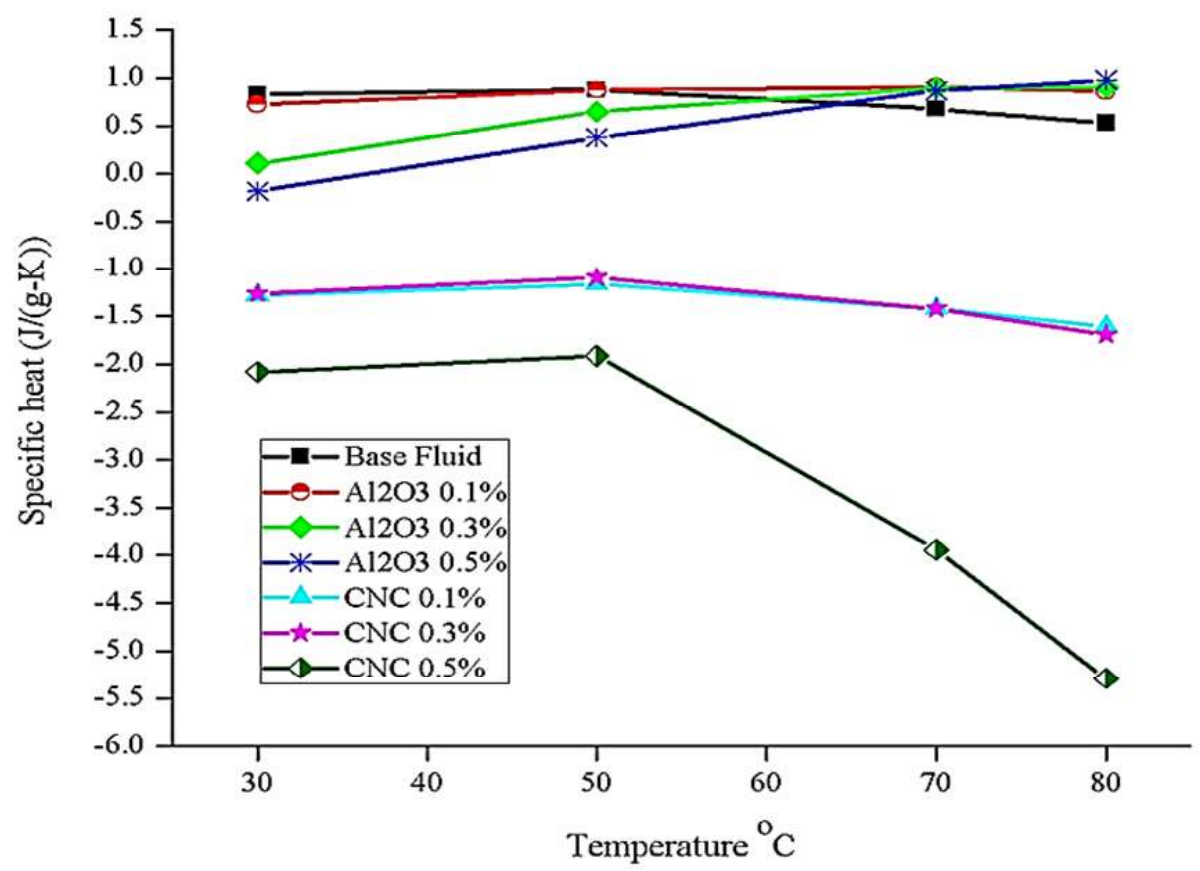

Fig. 17. Evaluation of specific heat of $\mathrm{Al}_{2} \mathrm{O}_{3}$ and $\mathrm{CNC}$ nanofluids correlated with temperature. 


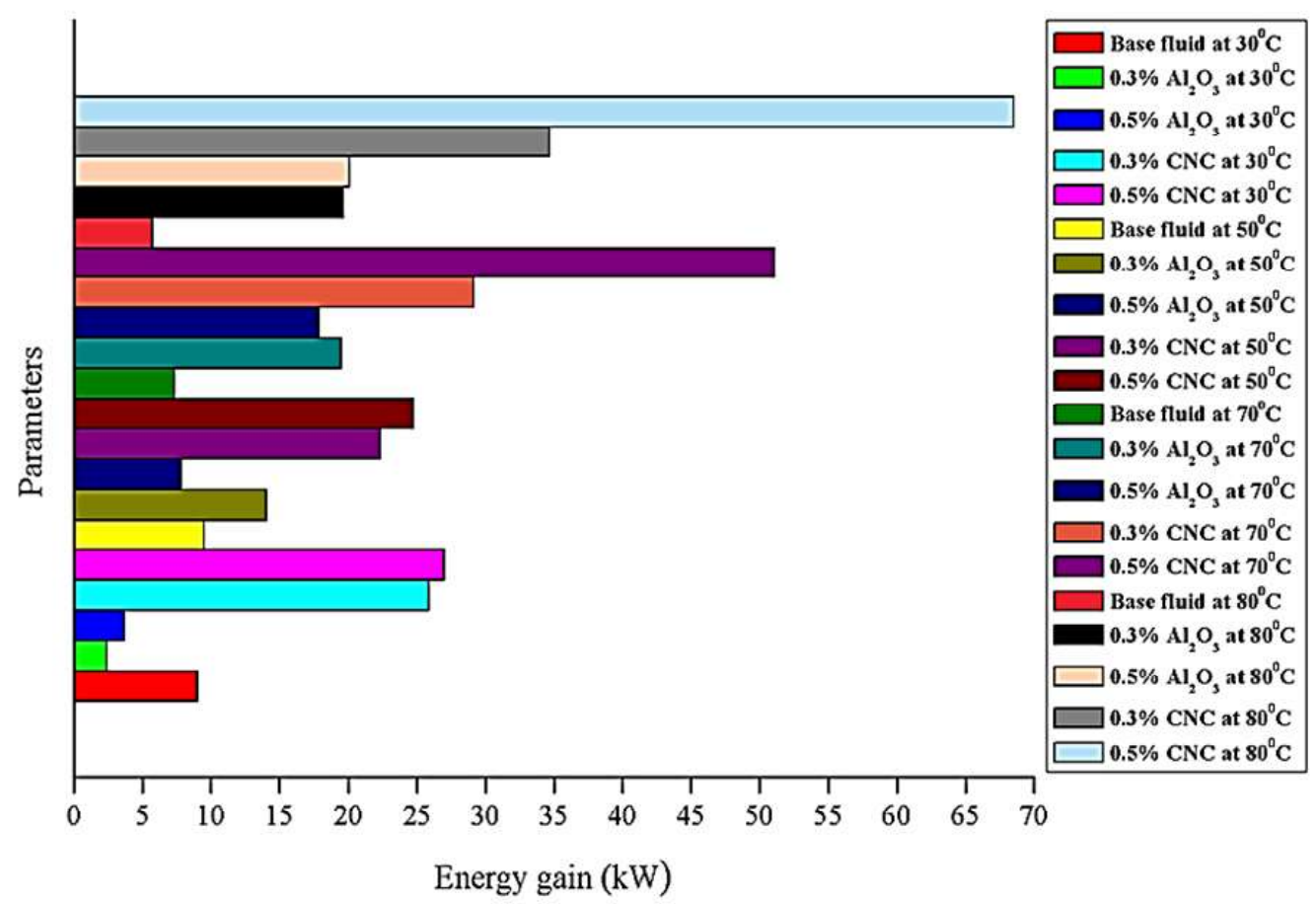

Fig. 18. Energy gain of flat plate solar collector. 


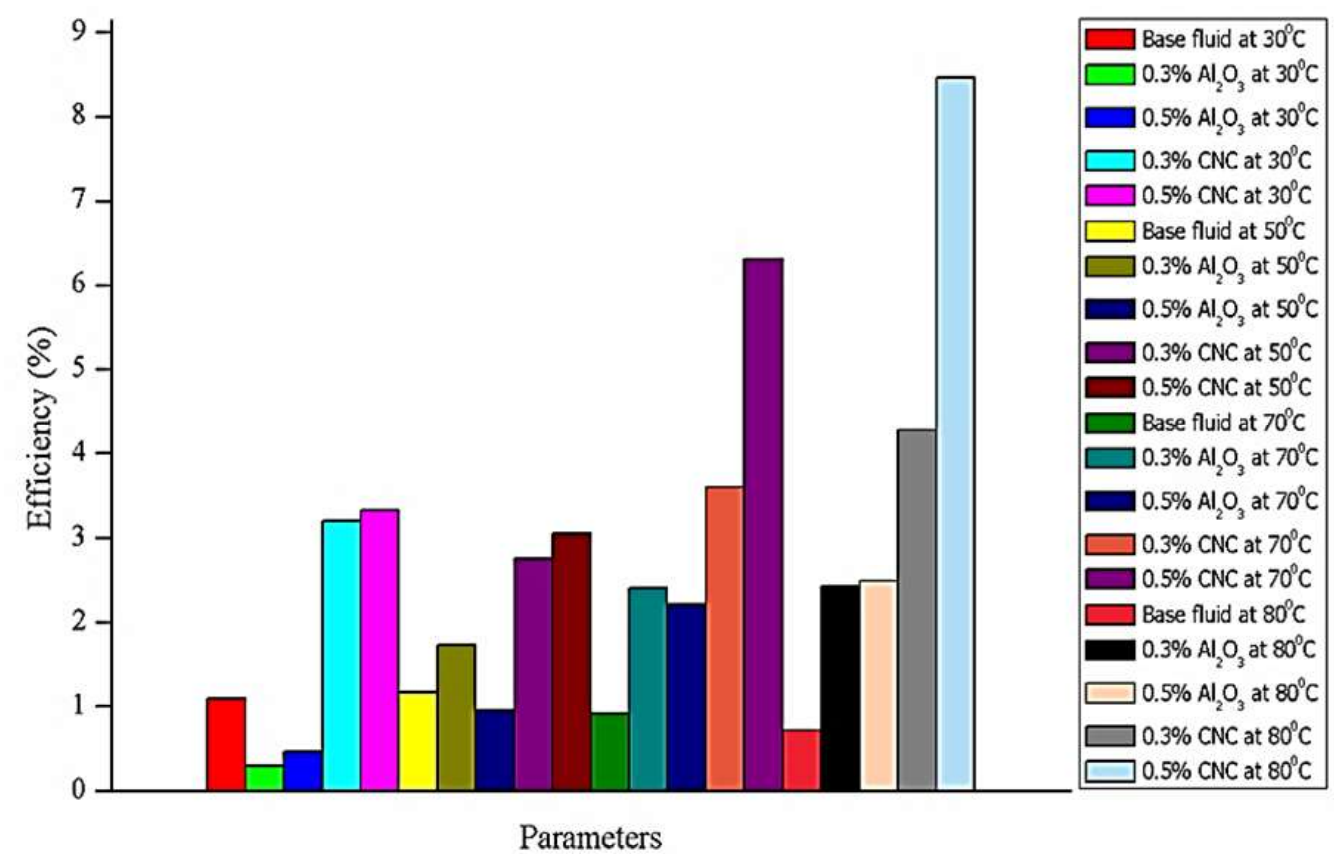

Fig. 19. Improvement of efficiency of flat plate solar collector. 


\section{List of Tables}

Table 1 Specification parameters of CNC [28].

Table 2 Specification of the tubes of FPSC.

Table 3 List of apparatus of the experimental setup of FPSC.

Table 4 Quantification results of $\mathrm{Al}_{2} \mathrm{O}_{3}$ nanoparticles.

Table 5 Quantification results of CNC nanoparticles.

Table 6 Evaluation of qualitative stability measurement of nanofluids.

Table 7 Experimental data of temperature $\left({ }^{\circ} \mathrm{C}\right)$ of nanofluids.

Table 8 Comparison of efficiency of FPSC with other research study. 
Table 1

Specification parameters of CNC [28].

\begin{tabular}{cc}
\hline Parameter & Value \\
\hline Crystallinity index & $80 \%$ \\
Crystal length & $100-150 \mathrm{~nm}$ \\
Crystal diameter & $9-14 \mathrm{~nm}$ \\
Hydrodynamic Diameter & $150 \mathrm{~nm}$ \\
\hline
\end{tabular}


Table 2

Specification of the tubes of FPSC.

\begin{tabular}{cc}
\hline Properties & Parameters \\
\hline Inner diameter & 12.5 \\
Outer diameter $(\mathrm{mm})$ & 12.7 \\
Number of tubes & 10 \\
Total length (m) of the tubes & 12.325 \\
Tube material & Copper \\
\hline
\end{tabular}


Table 3

List of apparatus of the experimental setup of FPSC.

\begin{tabular}{llll}
\hline Sr. no & Name of the apparatus & Characteristics & $\begin{array}{l}\text { Number of } \\
\text { apparatus }\end{array}$ \\
\hline 1 & Frame & Wooden & One \\
2 & Tubes & $\begin{array}{l}\text { Copper; outer diameter } 12.7 \mathrm{~mm} \text {; inner } \\
\text { diameter } 12.5 \mathrm{~mm} \text {; length } 1 \mathrm{~m}\end{array}$ & Ten \\
& Thermocouples & $\begin{array}{l}\text { Sensing element: coiled bimetallic } \\
\text { Electrical submersible filter }\end{array}$ & $\begin{array}{l}\text { Three } \\
\text { One }\end{array}$ \\
5 & Pump (Dolphin PA500) & $\begin{array}{l}\text { Elastic } \\
\text { Bucket }\end{array}$ & Ple \\
\hline
\end{tabular}


Table 4

Quantification results of $\mathrm{Al}_{2} \mathrm{O}_{3}$ nanoparticles.

\begin{tabular}{ccccc}
\hline Element & Weight \% & $\begin{array}{c}\text { Standard } \\
\text { deviation }\end{array}$ & Atomic \% & $\begin{array}{c}\text { Standard } \\
\text { deviation }\end{array}$ \\
\hline Oxygen, O & 49.49 & 5.34 & 59.73 & 3.36 \\
Aluminium, Al & 45.90 & 9.41 & 32.85 & 8.35 \\
\hline
\end{tabular}


Table 5

Quantification results of CNC nanoparticles.

\begin{tabular}{ccccc}
\hline Element & Weight \% & $\begin{array}{c}\text { Standard } \\
\text { deviation }\end{array}$ & Atomic \% & $\begin{array}{c}\text { Standard } \\
\text { deviation }\end{array}$ \\
\hline Carbon, C & 47.22 & 1.19 & 54.37 & 1.18 \\
Oxygen, O & 52.78 & 1.19 & 45.63 & 1.18 \\
\hline
\end{tabular}


Table 6

Evaluation of qualitative stability measurement of nanofluids.

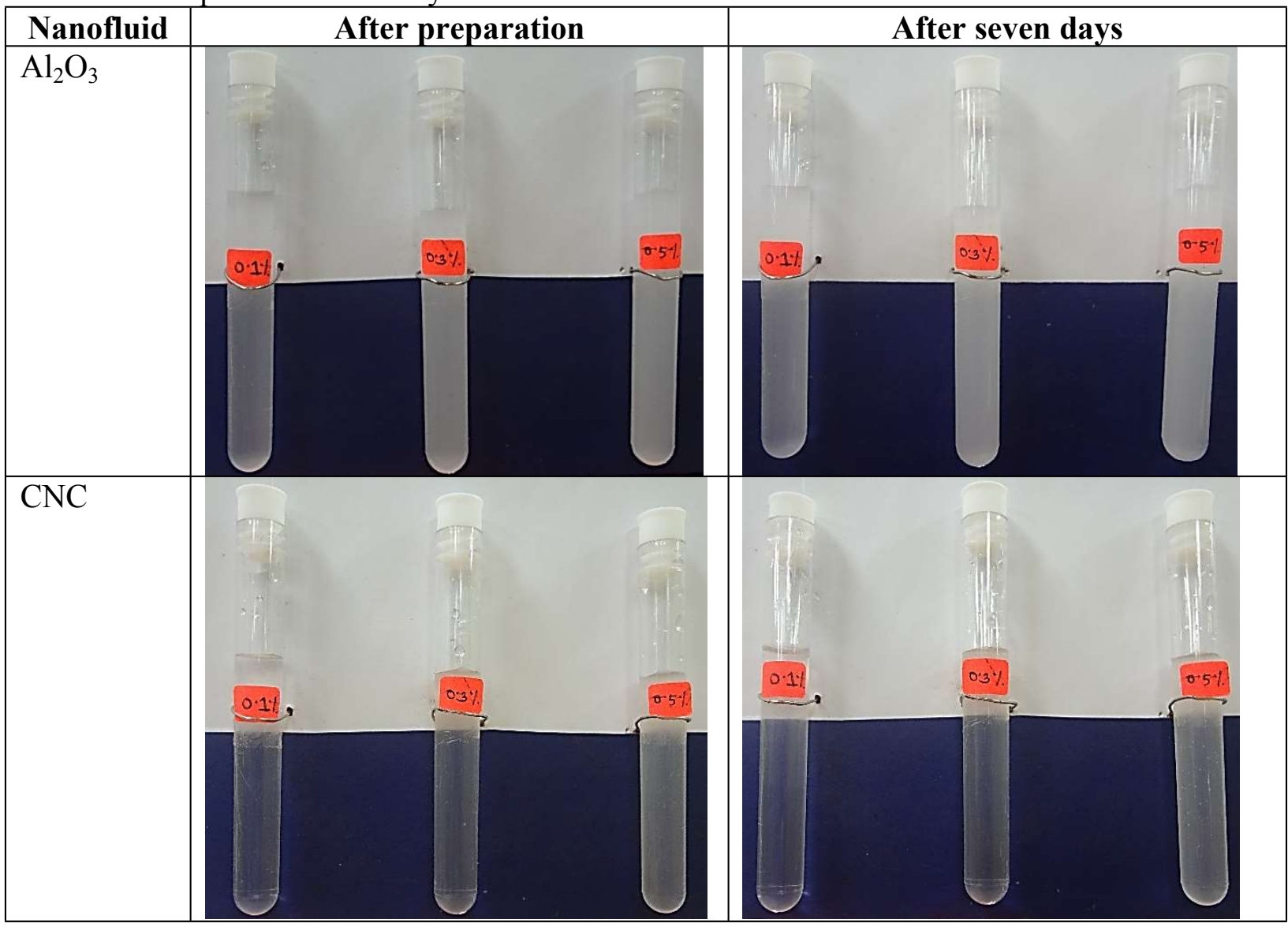


Table 7

Experimental data of temperature $\left({ }^{\circ} \mathrm{C}\right)$ of nanofluids.

Parameters

Outlet temperature $\left({ }^{\circ} \mathrm{C}\right)$

Inlet temperature $\left({ }^{\circ} \mathrm{C}\right)$

Base fluid

42.66

41.66

$0.3 \% \mathrm{Al}_{2} \mathrm{O}_{3}$

42.4

40.4

$0.5 \% \mathrm{Al}_{2} \mathrm{O}_{3}$

45.1

43.2

$0.3 \% \mathrm{CNC}$

44.88

42.9

$0.5 \% \mathrm{CNC}$

43.6

42.4 
Table 8

Comparison of efficiency of FPSC with other research study.

Nanofluids

$\mathrm{CNC} /$ water-EG

$\mathrm{SiO}_{2} /$ water-EG

$\mathrm{Al}_{2} \mathrm{O}_{3} /$ water-EG
Efficiency (\%)

Experimental results

8.46

2.48

Meibodi, Kianifar [49] 


\section{Declaration of interests}

प The authors declare that they have no known competing financial interests or personal relationships that could have appeared to influence the work reported in this paper.

$\square$ The authors declare the following financial interests/personal relationships which may be considered as potential competing interests: 